\title{
Venture Capital-Backed Firms, Unavoidable Value-Destroying Trade Sales, and Fair Value Protections
}

\author{
Casimiro A. Nigro ${ }^{1}$. Jörg R. Stahl ${ }^{2}$
}

(c) The Author(s) 2021

\begin{abstract}
This paper investigates the implications of the fair value protections contemplated by the standard corporate contract (i.e., the standard contract form for which corporate law provides) for the entrepreneur-venture capitalist relationship, focusing, in particular, on unavoidable value-destroying trade sales. First, it demonstrates that the typical entrepreneur-venture capitalist contract does institutionalize the venture capitalist's liquidity needs, allowing, under some circumstances, for counterintuitive instances of contractually-compliant value destruction. Unavoidable value-destroying trade sales are the most tangible example. Next, it argues that fair value protections can prevent the entrepreneur and venture capitalist from allocating the value that these transactions generate as they would want. Then, it shows that the reality of venture capital-backed firms calls for a process of adaptation of the standard corporate contract that has one major step in the deactivation or re-shaping of fair value protections. Finally, it argues that a standard corporate contract aiming to promote social welfare through venture capital should feature flexible fair value protections.
\end{abstract}

Keywords Private equity $\cdot$ Venture capital $\cdot$ Start-ups $\cdot$ Entrepreneurship · Innovation $\cdot$ Corporate governance $\cdot$ Private ordering $\cdot$ Drag-along rights $\cdot$ Trade sales $\cdot$ Corporate law $\cdot$ Fair value $\cdot$ Appraisal rights $\cdot$ Law and economics $\cdot$ Law and finance

\footnotetext{
This piece largely builds on Casimiro A. Nigro's PhD dissertation (see Nigro 2019) and the ensuing discussions with Jörg R. Stahl during his stay as a visiting researcher at the Center for Advanced Studies on the Foundations of Law and Finance. It is entirely the result of the cooperation between the authors. However, Italian regulation on academic evaluation requires a clear indication as to authors' individual contribution. For this purpose alone, Casimiro A. Nigro has prepared Sects. 1-6; while the authors have written Sect. 7 together.
}

Casimiro A. Nigro

nigro@lawfin.uni-frankfurt.de

Extended author information available on the last page of the article 


\section{Introduction}

Venture capital is disproportionately associated with innovation and, hence, economic growth. ${ }^{1}$ Everyday life delivers tangible and compelling evidence of this correlation. Tellingly enough, today's largest companies by market capitalization (i.e., Apple, Alphabet, Microsoft, and Amazon), like many other firms that have ended up disrupting market equilibria and consumer habits in recent times, ${ }^{2}$ were once just nascent business opportunities that venture capital helped grow from trailblazing but insecure start-ups to their current level of deep-rooted global influence. ${ }^{3}$

Given venture capital's importance to the economy, it is not surprising that the subject has attracted considerable interest from scholars and policymakers alike.

Social scientists, particularly economists and lawyers, have devoted significant attention to the various problems that emerge during the venture capital investment lifecycle, ${ }^{4}$ particularly as regards the dynamics unfolding throughout the entrepreneur-venture capitalist relationship..$^{5}$ Above all, they have subjected the highly unusual financial structure and corporate governance model of venture capital-backed firms - well known for being the function a myriad of private ordering-based solutions that reshape the standard corporate contract almost in its entirety ${ }^{6}$ - to

\footnotetext{
1 See, e.g., Kortum and Lerner (2000); Samila and Sorenson (2011); Popov and Roosenboom (2013); Faria and Barbosa (2014); Cheng et al. (2019).

2 See, for some examples, Lerner and Nanda (2020), p 5.

3 See Pollman (2019), p 156 (also adding details and relevant references).

4 For references, see, e.g., Fried and Ganor (2006), pp 969-971, fnn. 4-8, as well as Nigro (2020), pp 1-2, fnn. 2-5.

5 Although reference herein is made to the contractual framework governing the relationship between an entrepreneur and $a$ venture capitalist, reality is often more complex. In fact, multi-party parties often sit on both sides of this sort of relationship. Venture capitalists typically syndicate investments: see, for instance, Klausner and Litvak (2001), pp 11-12; as well as, more extensively, Lerner (1994). And it is not rare for entrepreneurs to be a group of individuals-i.e., an entrepreneurial team. See, for instance, Broughman and Fried (2013), p 1323. Not introducing the resulting complexity in the relationship helps to limit the scope of the discussion, which would otherwise need to encompass problems concerning intra-group conflicts. On these conflicts see Klausner and Venuto (2013), instead.

6 The standard corporate contract is the 'template' that corporate law provides to prospective business partners. See_building on Coase (1937)_-Hart (1989), p 1764 and Easterbrook and Fischel (1989), p 1418, as well as Armour et al. (2017a), p. 2. Therefore, the locution 'standard corporate contract' is just another way of referring to corporate law. Throughout this article, the locution 'corporate contract' refers to the whole set of formally distinct but functionally and operationally intertwined contracts that govern the entrepreneur-venture capitalist business relationship-from the constitutional documents to shareholder agreements. See e.g., Bengtsson (2012), p 486. The corporate contract is the function of different types of legal rules. The main divide is between mandatory and default rules. Mandatory rules apply whether or not the contracting parties elect to be covered. Mandatory rules can be either (i) avoidable rules, which by their terms do not permit 'opting out', but which may be avoided (i.e., contracted around), for instance through contract; and (ii) binding rules, which are impossible to avoid. By contrast, default rules permit contracting parties to 'opt out'. On the matter, see Easterbrook and Fischel (1989), as well as Coates (1999), p 1255, fn. 9. As to the myriad of private ordering-based arrangements defining the venture capital-backed firm's financial structure and governance model, see, e.g., Cumming and Johan (2009).
} 
extensive scrutiny. This strand of research has shed light, in particular, on the potentially significant impact that the resulting allocation of cash flow rights can have on the decision-making process that precedes so-called 'trade sales'—roughly speaking, a variety of M\&A transactions instrumental to carrying out the sale of the entire venture capital-backed firm. ${ }^{7}$ The key message that this scholarship has delivered is that the arrangements that are typical of venture capital-backed firms expose the entrepreneur to the risk that the venture capitalist "in control' ${ }^{8}$ may, under some circumstances, carry opportunistically out premature value-destroying trade sales. ${ }^{9}$ These transactions, in departing from the total shareholder value maximization norm that governs contract implementation, ${ }^{10}$ typically advance the interest of the venture capitalist, leaving the entrepreneur, qua shareholder external to decisionmaking, worse-off. ${ }^{11}$

\footnotetext{
${ }^{7}$ See chiefly Fried and Ganor (2006). Another note on terminology (for the uninitiated): M\&A stands for 'mergers \& acquisitions', which — as per Coates IV (2018), pp 571-572—is simply a 'business term' referring to a variety of transactions instrumental to realize a 'deliberate transfer of control of ownership of a business'. Mergers are perhaps the simplest example. The M\&A market is, thus, the market for corporate control. For more details and references on the market for corporate control, see, e.g., Kershaw (2016), pp 1-30.

${ }^{8}$ In venture capital-backed firms, control is a fluid concept. It not only varies throughout the lifecycle of the firms, but is also allocated in a fragmentary manner: A venture capitalist holding no residual control may nonetheless be, because of specific control-rights, in control of the divestment process. See below, Sect. 2.2.2, particularly nn. 67-70 and corresponding text as well as Sect. 3.1, especially nn. 83-85 and corresponding text. References throughout this piece to the venture capitalist in control are to be read accordingly-i.e., as references to the venture capitalist in control of the divestment process and, in particular, of the process that leads to trade sales.

${ }^{9}$ As in Fried and Ganor (2006), p 971, fn. 13, the term 'opportunistic' here refers to self-serving decision-making that reduces the value available to all parties affected by the resulting decision. For specifications, see below, $\mathrm{n}$. 10. This is consistent with the conceptualization of opportunism as 'self-interest seeking with guile' brought in by Williamson (1975), p 255.

${ }^{10}$ Absent frictions, contracts are ex ante value-maximizing by definition. Also, their implementation generally obeys, albeit only by default, the joint value maximization norm. Decision-making ought therefore to maximize joint value, regardless of how the contract has allocated authority and will allocate the resulting value. See, e.g., Schwartz and Scott (2003), pp 550-554. The corporate contract is no exception. Not only it is presumably ex ante value-maximizing, but it also obeys, by default, the logic of firm value maximization: see, respectively, Easterbrook and Fischel (1989), p 1421 and Armour et al. (2017a), $\mathrm{p} 23$. This is in line with the corporate finance lesson that intra-firm decision-making ought to be instrumental to the maximization of firm value regardless of how its community of investors will capture the resulting wealth. See, e.g., Damodaran (2010), p 3 (reporting that ' $[\mathrm{t}]$ he objective in conventional corporate financial theory when making decisions is to maximize the value of the business or firm'). Assuming for the purposes of the discussion articulated herein the absence of other constituencies (e.g., creditors, workers), firm value is joint value and, more specifically, total shareholder value. Therefore, this paper will deploy these terms interchangeably, occasionally resorting to the abbreviation 'TSV'.

${ }^{11}$ For details, see, chiefly, Fried and Ganor (2006), pp 981-999 (analysing these transactions based on the observation of a scenario in which the venture capitalist holds non-participating liquidation preferences). See, also Nigro (2020), pp 5-10 (considering the specular scenario in which the venture capitalist holds participating liquidation preferences). The locution 'shareholder external to decision-making' may sound redundant, for it clearly refers to non-controlling shareholders. While deployed with such a meaning in the context of an extensive corporate law scholarship, the equation between shareholders external to decision-making and non-controlling shareholders may prove misleading in the context of the discourse concerning venture capital-backed firms because of the peculiar arrangements that result in a fluid allocation of control. See above, n. 8 .
} 
As part of a broader set of strategies to engineer a vivid venture capital market, policy-makers, particularly in Europe, ${ }^{12}$ have drawn upon the debate stressing the importance of a flexible standard corporate contract for the facilitation of bargaining among entrepreneurs and venture capitalists to motivate their significant efforts towards modernizing it. ${ }^{13}$ Initiatives have in fact flourished to remove the rigidities of the standard corporate contract most manifestly incompatible with venture capital as a mode of financing and, thereby, encourage the formation of new partnerships between entrepreneurs and venture capitalists. ${ }^{14}$

Both the scholarly discussion and the policy debate have, however, been limited in scope. On the one hand, scholars have focused chiefly on explicit contractual contents and on addressing the threat of opportunism rather than discussing whether, due to implicit contractual contents, ${ }^{15}$ there might be instances of non-opportunistic value-destruction through trade sales. On the other hand, in their attempts to modernize the standard corporate contract, policy-makers have generally been concerned with making the room for the arrangements responsible for the static structure of venture capital-backed firms - namely, those that chiefly concern their financing. ${ }^{16}$ At least thus far, they have neglected to consider whether other terms of the standard corporate contract can prove problematic when the venture capital-backed firm is viewed in terms of its evolution. This is particularly true-as it will soon be clearwith regard to the way in which the standard corporate contract can distort the allocation of value generated through the transactions whereby the venture capitalist typically divests-particularly trade sales.

This piece of research aims to complement existing scholarship concerning the dynamics of venture capital-backed firms, particularly in the run-up to trade sales, while also engaging with the policy discussion concerning the optimal design of the corporate contract for the purposes of supporting venture capital investments.

To this end, it mounts an investigation into unavoidable value destroying trade sales and the role that the fair value protections contemplated under the standard corporate contract play in preventing the entrepreneur and the venture capitalist from designing the arrangements that fit their desiderata. 'Unavoidable value destroying trade sales' are trade sales that the venture capitalist in control executes towards the end of the lifetime of the venture capital fund to generate the liquidity needed to meet his obligations towards his own investors and which, due to various

\footnotetext{
12 For details as to these strategies and references, see, e.g., Vermeulen (2018).

13 The claim that legal flexibility (in general) is of paramount importance in supporting the complex private ordering-based infrastructure that supports venture capital investments is well-known. See, chiefly, Gilson (2003), p. 1069. More or less assertive and broad claims as to the connection between a flexible corporate law and venture capital investments have since appeared in an extensive body of literature. See Baums and Möller (1999), p 1; Enriques and Macey (2001), p 1203; Armour (2003), p 139; Vermeulen (2003), pp 303-309; McCahery and Vermeulen (2003), pp 173-178; Giudici and Agstner (2019), p 606.

14 In recent years, national policy-makers in Europe have subjected their corporate laws to more or less extensive reforms aiming to modernize the regulatory apparatus: see Neville and Sørensen (2014), pp 550-554; and Giudici and Agstner (2019), pp 612-613.

15 'Implicit contracts' are 'the unarticulated but (presumably) shared expectations that the parties have concerning the relationship'. See, Milgrom and Roberts (1992), p 132.

16 For details, again Neville and Sørensen (2014), pp 550-554; and Giudici and Agstner (2019), pp 612613.
} 
contingencies, end up sacrificing total shareholder value. 'Fair value protections', refer, in functional terms, to a number of safeguards and remedies entitling shareholders external to decision-making to claim the pre-transaction value of their shares (simply 'fair value'), taken to be a function of firm value, vis-à-vis a given list of actually or potentially value-destroying transactions, so as to possibly escape their negative consequences. ${ }^{17}$

First, it demonstrates that the typical entrepreneur-venture capitalist contract goes to great lengths to prioritize the venture capitalist's liquidity needs, allowing, under some circumstances, for instances of counterintuitive contractually-compliant value destruction. The venture capitalist is in fact endowed, by means of an implicit contractual term, with a 'termination option' that enables him, albeit only at a given point in time, to go for a timely divestment regardless of any contingency and any possibly ensuing consequence. Unavoidable value-destroying trade sales are the most tangible example. Next, it argues that fair value protections can prevent the entrepreneur and venture capitalist from allocating the value that these transactions generate as they would want. Then, it shows that the reality of venture capital-backed firms calls for a process of adaptation of the standard corporate contract that has one major step in the deactivation or re-shaping of fair value protections. Finally, it argues that a standard corporate contract aiming to promote social welfare should contemplate flexible fair value protections.

The analysis seeks to achieve two goals. It aims at providing a more granular theoretical understanding of the drivers behind value-destroying trade sales as well as delivering to policy-makers a suggestion for the optimal design of an important but thus far under-investigated term of the standard corporate contract. As such, it contributes to both the scholarly discussion about the dynamics unfolding in venture capital-backed firms and to the policy debate concerned with defining the recipe for modernizing the standard corporate contract with a view to delivering prospective entrepreneurs and venture capitalist with a more malleable product.

In addition to this introduction, this piece unfolds in six major steps. Section 2 offers a primer to the evolving structure of venture capital-backed firms and an account of the crucial role of the termination option in institutionalizing, though only partly, the venture capitalist's interest to pursue his own liquidity needs. Building on this novel theorization of venture capital-backed firms, Sect. 3 sheds light on the dynamics underlying unavoidable value-destroying trade sales and accounts for their counterintuitive contractually-compliant nature. Section 4 projects the

\footnotetext{
17 A very simple example may help shed light on the operational features of fair value protections. Consider Alfa, a company with a $75 \%$ controlling shareholder CS who makes decision and another $25 \%$ shareholder external to the decision-making process MS. Assume also that firm value is 100 and that, this notwithstanding, MS causes Alfa to a merger with Beta. Assume, finally, that for the purposes of the transaction Alfa's value stands at—say-50 (perhaps because CS has received his extra-payment through another channel-i.e., a side-payment). Fair value protections enable MS to claim $25(=100 * .5)$ instead of the lower figure (i.e., $12.5=50 * .25$ ) that he would receive as a result of the transaction. Intuitively, the remedy would still be available even if Alfa in the merger were to be valued at 150 . Yet, as in this case MS would get 37.5 instead of 25 , he would be better-off by not triggering the fair value protection. Fair value protections have their prototypical example in the appraisal right that Delaware corporate law makes available to shareholders who have dissented from a number of transactions (e.g. mergers); as well as their European counterparts (e.g., the so-called 'diritto di recesso' available vis-à-vis a given list of transactions under Italian corporate law). For details and references, see below, Sect. 4.1.
} 
discussion into its legal dimension: it outlines the response of the standard corporate contract to value-destroying trade sales by addressing fair value protections. It then accounts for their problematic implications and the reasons for their potential 'failure' in the context of venture capital-backed firms. Section 5 focuses on one major step of the complex process instrumental to adapting the corporate contract to the specific features of venture capital-backed firms: the deactivation or re-shaping of fair value protections. Section 6 takes on a normative bent to argue that policymakers interested in attracting venture capital to promote social welfare should build flexibility into fair value protections. Section 7 concludes by summarizing the terms of the discussion and outlining avenues for complementary research.

Three important caveats narrow the scope of the discussion articulated herein. First, as the discussion is exclusively focused on unavoidable value-destroying trade sales and fair value protections, it is deliberately unconcerned with the opportunistic premature value-destroying trade sales that the venture capitalist in control may carry out and the fiduciary standards that are generally at work in protecting the entrepreneur from their negative effects. ${ }^{18}$ Second, as the discourse is merely conceptual in nature and aims to deliver only normative recommendations, it does not seek to extend its reach into the analysis of existing positive realities. ${ }^{19}$ Third, as the analysis is concerned with venture capital-backed firms, it does not address the implications that the flexibility of fair value protections has on other firms - say, somewhat generically but herein rather usefully, 'ordinary firms'. ${ }^{20}$

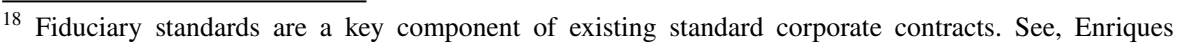
et al. (2017), p 88 (discussing fiduciary standards in general) and Rock et al. (2017), p 188 (discussing the role of such standards as regards fundamental transactions). These standards have different legal names, depending on the jurisdictions. This notwithstanding, they all seek to fill a gap in an incomplete contract. On the functional equivalence of these standards, despite their denominations, see Pargendler (2008). Such fiduciary standards tend to apply to many of the various transactional forms that trade sales can take in practice. In principle, they have the potential to protect the entrepreneur from opportunistic premature value-destroying trade sales-albeit more or less effectively, depending on a number of institutional variables. Indeed, the problem with 'traditional' fiduciary standards is that they are generally not designed so as to cope with the evolving structure of venture capital-backed firms. For input in this respect, see Fried and Ganor (2006), pp 999-1001 and 1020-1024; and Bratton and Wachter (2013), pp 1882-1900. For a blueprint for a more extensive discussion of fiduciary standards in the context of venture capital-backed firms, see Nigro (2020).

${ }^{19}$ See, for a preliminary discussion that focuses on fair value protections in the context of trade sales under both US and Italian corporate law, Nigro and Maltese (2020). For a far more extensive (comparative) discussion (regarding also Germany), see instead Giudici et al. (2020).

${ }^{20}$ For the purposes of this discussion 'ordinary firms' are all the firms that are not venture capitalbacked firms. For more details and an in-context use of this terminology, as well as references, see below, n. 123 and corresponding text.
} 


\section{The Evolving Structure of Venture Capital-Backed Firms}

A relatively recent scholarship has attempted to complement the extensive literature discussing specific moments within the lifecycle of the prototypical venture capital-backed firm ${ }^{21}$ by characterizing its evolving structure, that is, the organizational changes that occur within these firms over time. ${ }^{22}$ Time, however, also marks a progressive increase in the importance of divestment as venture capital-backed firms mature, ${ }^{23}$ ultimately driving profound changes that, in addition to organizational modifications of the structure of these firms, eventually affect also their 'existential purpose'. This transition has its origin in the unique contents of the contract negotiated by the entrepreneur and the venture capitalist.

\subsection{The Entrepreneur and the Venture Capitalist}

Much modern-day innovation owes itself to the entrepreneur ${ }^{24}$ : an agent of change eager to alter existing market equilibria with an ultimate view to capturing a discrete share of the ensuing wealth, ${ }^{25}$ perhaps by selling his creature to a competitor. ${ }^{26}$

The current entrepreneur looks more and more like an MBA, with an at least decent knowledge of the complexity of the entrepreneurial process and the resources that it requires. ${ }^{27} \mathrm{He}$ knows that the capital-intensive nature of his innovative project will soon require external capital. ${ }^{28}$ Above all, he knows that, due to the high risk

\footnotetext{
21 On which see, e.g., Fried and Ganor (2006).

22 See, comprehensively, Pollman (2019) (pointing out that venture-backed startups involve heterogeneous shareholders in overlapping governance roles that give rise to vertical and horizontal tensions between founders, investors, executives, and employees; and that these tensions tend to multiply as the company matures and the number of participants with varied interests and claims increases). Earlier in time, see also Bartlett III (2006).

23 At its core, this claim goes back to Gordon Smith (2005) (discussing the exit-structure of venture capital-backed firms).

${ }^{24}$ Innovation stems to a large extent from independent entrepreneurs but it has various loci: see, at length Gilson (2010) (discussing the matter and explaining that the by-now proverbial lean start-ups led by innovative entrepreneurs compete with other realities in bringing innovative products and services down to the market).

25 Accounts of entrepreneurs that emphasize their inclination to disrupt markets are commonplace in the literature: see, e.g., Hebert and Link (1988), p 155. Entrepreneurs make huge firm-specific investments that most of the times result in an undiversified exposition to firm idiosyncratic risk: see, Hall and Woodward (2010), p 1163; as well as Smith (2012), pp 451-452.

${ }^{26}$ Recent research has pointed out that the entrepreneurs of today look for capital to build companies that may be acquired by market incumbents in the relatively near future: see, e.g., Lemley and McCreary (2020), pp 46-47. This is indeed poised to be an 'inherent' part of the entrepreneurial process: see DeTienne (2010). This is not to mean that to sell the firm to a competitor is the ambition of every entrepreneur, but just to provide a plausible key to read the behaviour of many of them.

27 Zider (1998), p 132. This is not to say that innovative entrepreneurs always have a specific degree. Rather, it means that they know quite a bit about entrepreneurship- and business-related matters.

${ }^{28}$ Entrepreneurs are typically wealth-constrained. See, e.g., Hall and Woodward (2010), p 1165. They resort to personal and relational capital during the very early stages of the entrepreneurial process, but the tendency of innovative projects to be 'quick cash-burning machines' makes these sources of capital of generally limited aid. See, Robb and Robinson (2014).
} 
of his project and the failures that plague the market for entrepreneurial finance, ${ }^{29}$ the viability of his potentially revolutionary idea will not hinge upon the traditional banking intermediation circuit. Rather, his ambition to actually bring down to the market his disruptive product or service will crucially depend on establishing a partnership with a venture capitalist.

The venture capitalist is a type of financier known, even among the uninitiated, for his informational advantage in selecting high-tech business projects and, above all, for committing to supporting them for a short-to-medium time-period. ${ }^{30}$

The inherently transient nature of the venture capitalist's commitment reflects the dynamics underlying the 5-to-8-year venture capital investment lifecycle. ${ }^{31}$ The prototypical venture capitalist begins by raising capital from a variety of investors ${ }^{32}$ promising to deliver certain returns within a given period. Second, he carefully selects business projects based on their 'exit potential' so as to establish the preconditions for the punctual implementation of the promises that he has made to his own investors. ${ }^{33}$ Third, he nurtures his portfolio companies by deploying a 'hands-on' approach that combines financial and non-financial contributions ${ }^{34}$ so as to accelerate the value creation process within a given timespan. Fourth, the venture capitalist 'harvests' his portfolio through a variety of techniques, ${ }^{35}$ including trade sales. A relatively small number of 'winners' will generally make up for the modest

\footnotetext{
${ }^{29}$ On the obstacles that innovative entrepreneurs face in their attempts to obtain external finance and the consequences that originate from these attempts, see, chiefly, Lerner (2007), pp 403-409. As to the other recurring features of innovative firms, see, e.g., Gompers and Lerner (2001), p 145; Aghion et al. (2004), pp 327-331; Berger and Udell (1998), p 616.

30 On these points, see, e.g., Amit et al. (1998), p 444; Aghion et al. (2004), p 327. See also Lerner (2007), pp 408-412.

31 The literature traditionally suggests that venture capital funds have a 5-to-10 year timespan. See, e.g., Sahlman (1990), pp 490 and 493-494; and, above all, Gilson (2003), pp 1089-1090. More recent research suggests, however, that their lifecycle unfolds in 5-to-8 years. See, above all, Lerner and Nanda (2020), p 14. The contract governing venture capital funds sometimes stipulates that an extension of the fund lifetime for one or two years is possible, contingent upon prior approval by the investors. See, e.g., Cumming and Johan (2009), p 96; and, again, Lerner and Nanda (2020), p 14.

32 These investors range from pension funds, banks, and insurance companies to endowments as well as family offices, and, though to a minor extent, other sources. See, Cumming and Johan (2009), pp 4 and 603-631.

33 A venture capitalist is mainly "naturally drawn to investment opportunities where the ideas can be commercialized and their value realized through an "exit" within a reasonably short period': Lerner and Nanda (2020), p 8.

${ }^{34}$ Non-financial contributions come in the form of mentoring, strategic advice, network resources, and social and political capital: See, also for references, e.g., Black and Gilson (1998), pp 252-255 and Black and Gilson (1999), pp 40-41.

35 Venture capitalists can realize their investments through (1) initial public offerings (IPOs); (2) trade sales; (3) redemptions of the venture capitalist's shareholding (pursuant, for instance, to a contractual put option right or otherwise by making the contractual bed for the redeemability of their shareholdings); or (4) liquidation of the portfolio company and subsequent cash distribution to its shareholders (so-called 'write-off'). See, for instance, Gordon Smith (2005), p 339.
} 
profitability or failure of the majority of his investments, ${ }^{36}$ leading to overall healthy portfolio returns.

The exit-oriented approach that dominates the investment process has a clear efficiency-based rationale that has its ultimate roots in the organizational features of the venture capital industry. Venture capital funds typically take the form of a limited partnership with venture capitalists as general partners and investors as limited partners. ${ }^{37}$ The choice of this scheme serves to give the venture capitalist full control over the wealth of fund investors so as to enable him to make decisions in a fast-changing business environment. ${ }^{38}$ Although operationally efficient, the resulting control-related arrangements may generate room for the venture capitalist to engage in various forms of opportunism that contracts typically seek to counteract by way of a number of devices. ${ }^{39}$ The most important such device is the provision stipulating a fixed term for the venture capital fund. ${ }^{40}$ Much like a contractually imposed takeover, the fixed-term provision subjects the venture capitalist's performance to a market assessment before investors come to a decision as to whether they want to reentrust their capital in the next capital raising campaign. ${ }^{41}$

In order to encourage his investors to further extend their trust as the investment lifecycle begins anew, the venture capitalist must keep his promises from the capital raising stage ${ }^{42}$ : Yielding appropriate returns in a reliably timely fashion is then the essential precondition for the long-term viability of his business. ${ }^{43}$

\footnotetext{
36 The rule of thumb in venture capital industry is that about $30 \%$ of the portfolio companies will be 'winners', $40 \%$ will be 'losers', and 30\% will end up being so-called 'living dead' or 'sideways firms' (because of, e.g., declining customers, falling demand, lack of cash, poor future business prospects, execution mistakes, etc.). See, e.g., Ruhnka and Young (1991), p 119. Winners generate a 25-35\% yearly return. A living dead typically stays alive and progresses modestly but generates lower returns than wellperforming venture capital-backed firms - approximately in between 1 and 20\% per year. Losers generate losses in the range of about 9\% per year. For details, see Smith (2012), pp 456-459.

37 See Gilson (2003), pp 1070-1071.

${ }^{38}$ See, again, Gilson (2003), p 1088.

${ }^{39}$ For a discussion as to the arrangements limiting decision-makers' opportunism in this context (from covenants to co-investment and compensation schemes) see, Sahlman (1990), pp 489-493; Klausner and Litvak (2001), pp 13-14; Gilson (2003), pp 1087-1090; Litvak (2009), pp. 169-182; Birdthisle and Todd Henderson (2009); Cumming and Johan (2009), pp 147-149; and Krumm (2017), pp 569-575.

${ }^{40}$ As to the standard duration of venture capital funds, see above, n. 31 and corresponding text. As to its importance as an anti-opportunism device, see Gilson (2003), pp 1089-1090.

${ }^{41}$ See, chiefly, again Gilson (2003), pp 1089-1090; as well as Black and Gilson (1998), pp 255-256; and Black and Gilson (1999), p 41.

${ }^{42}$ See, chiefly, Gilson (2003), p 1091 (discussing venture capitalists' incentives to realize investments so as to generate evidence of skilfulness that can be used as 'the primary tool for persuading investors to provide capital for successor funds').

${ }^{43}$ See, e.g., Gordon Smith (2005), p 345 (discussing timely divestment from portfolio firms as a must for venture capitalists willing to generate timely returns and, thus, remain in business).
} 


\subsection{The Contract}

The non-standardized contractual framework that the entrepreneur and the venture capitalist typically piece together plays a fundamental role in supporting the efficient implementation of the contract governing the venture capital fund. ${ }^{44}$

Consistent with the two facts the negotiations among the contracting parties do take into consideration mainly the high riskiness of the project presented to the venture capitalist and the entrepreneur's awareness that no forever marriage is in sight,${ }^{45}$ this contractual framework does in fact obeys a generally stable twofold functional logic. ${ }^{46}$

First, the entrepreneur-venture capitalist contract is concerned with removing obstacles that stand directly in the way of financing innovative projects. ${ }^{47}$ Contracts make recourse to a variety of private ordering-based solutions to mitigate the potentially deal-inhibiting implications of extreme uncertainty, informational asymmetry and moral hazard that typically emerge in this context. ${ }^{48}$ Among these private ordering-based solutions are-inter alia $^{49}$ - so-called 'liquidation

\footnotetext{
${ }^{44}$ On the negotiated and, thus, non-standard nature of these contracts, see, e.g., Baird and Henderson (2008), p 1328. During negotiations, both the entrepreneur and, of course, the venture capitalist benefit from the assistance of lawyers: see Bengtsson (2012), p 485-486.

${ }^{45}$ The (non-naïve) entrepreneur typically invests based on the awareness that the venture capitalist offers his 'services' for a limited period of time. This is an obvious consequence of the sophistication of the entrepreneur portrayed herein: see above, nn. 27-29 and corresponding text. For a confirmation, see, e.g., Gompers et al. (2019), p 712 (recalling a meaningful anecdote about an entrepreneur who, in the run-up to the meeting during which the decision would be taken whether to sell the firm or not, noted that 'I was certainly naïve about a lot of things, but one thing I definitely understood when I took [the venture capitalist's] money was that the day would come when we would need to do something to get [the venture capitalist] a cash return on their capital. I needed the funds back in 1998 to grow the business, and we wouldn't be where we are today without it').

${ }^{46}$ The focus on the functional logic of the entrepreneur-venture capitalist contract allows to overlook formal variations that are observable both in time (i.e., over investment cycles) and space (i.e., jurisdictions). Entrepreneurs and venture capitalists can adopt a variety of contractual solutions depending on a number of factors-including, for instance, the evolution of contractual technology actually available and the overall institutional context where they start cooperating. In accounting for the peculiarities of the governance of venture capital-backed firms, a functional approach is thus required, so as to encompass the variety of contractual techniques to which prospective business partners may resort, overlooking the details of standard contractual arrangements that, while formally important, are of negligible significance throughout this article.

${ }^{47}$ See, chiefly, Gilson (2003), p 1078. For a more practical examination, instead, see, e.g., Gompers et al. (2019), pp 279-293.

${ }^{48}$ See, again, Gilson (2003), pp 1078-1087, as well as Kaplan and Strömberg (2003) and Kaplan and Strömberg (2004).

${ }^{49}$ A number of control-rights are at work here, too, of course: staged financing (and the abandonment option that it implicitly embeds), the right to remove the negligent or unskilled entrepreneur, and a variety of 'protective provisions' are all of importance and, although distinct, they may exhibit non-negligible synergies. For a general discussion, see Kaplan and Strömberg (2003) and Kaplan and Strömberg (2004). On staged financing see, Gompers (1995) and Gompers and Lerner (2001), pp 155-156; as well as Gilson (2003), pp 1078-1081. On the abandonment option embedded in staged financing and its economics, see, again, Gilson (2003), p 1085, as well as Bratton (2002), p 893 and Graham et al. (2016), p 701. Instead, on the venture capitalist's right to remove the unskilled or negligent entrepreneur, see, e.g., Broughman and Fried (2013), p 1347. On protective provisions see, briefly, Cumming and Johan (2009), p 390; and, for a more detailed discussion from a law and economics perspective, Gordon Smith (2005), p 346. For an interesting empirical analysis, see, Bengtsson (2012).
} 
preferences, ${ }^{50}$ which grant the venture capitalist a senior financial claim with regard to an amount generally equal to their original investment. ${ }^{51}$ This amount must be paid out preferentially in a number of 'liquidity events', which can be defined as transactions whereby illiquid investments made in the firm are eventually turned into cash. ${ }^{52}$ Liquidation preferences can have different 'sources' (originating, from the contract, a mix of securities, or, most likely, security design), and exhibit different designs (i.e., be 'non-participating' or 'participating'). ${ }^{53} \mathrm{At}$ their core, however, they all result from contracting parties' choice to come to the uneven allocation of entrepreneurial risk that is typically observable in venture capital-backed firms. ${ }^{54}$

On a more abstract level, the entrepreneur-venture capitalist contract is concerned with supporting the efficient implementation of the contract governing the venture capital fund. ${ }^{55}$ This contract is the result of 'braiding' - a technique

50 For the basics of liquidation preferences, see Maynard and Warren (2014), pp 496-500. As to the mechanics whereby liquidation preferences mitigate uncertainty, informational asymmetries, and moral hazard, see, e.g., Sahlman (1990), pp 510-511; Fried and Ganor (2006), p 983, fnn. 39 and 40 and corresponding text. See also below, n. 53 and corresponding text.

51 Liquidation preferences in an amount equal to a multiple of the original investments are not rare, though: see, also for additional references, Fried and Ganor (2006), p 982, fn. 37 and corresponding text. Importantly, liquidation preferences also go hand in hand with cumulative dividends-for which venture capitalists often push so as to obtain a minimum annual rate of return on their investments-making liquidation preferences even larger over time. Venture capitalists sometimes also require compounding. See again, e.g., Maynard and Warren (2014), pp 490-492 and 502-503.

52 Not all the transactions whereby venture capitalists divest are liquidity events. Liquidity events include, in particular, both trade sales and shareholding redemptions. See, e.g., Fried and Ganor (2006), p 993; and, more extensively, Maynard and Warren (2014), pp 493-496.

53 Liquidation preferences vary along two important dimensions that affect their actual mechanics. To begin with, liquidation preferences can exhibit different 'sources'. Although contract (i.e., either socalled 'waterfall provisions' in a company's constitutional documents or in a shareholder agreement) or an ad hoc balanced mix of securities (e.g., debt and equity) may, to some extent, be of use, liquidation preferences are usually the function of security design. For more information, see Nigro (2020), pp 11-16. Another dimension along which liquidation preferences differ is their design-i.e., they can differ in the manner in which they combine 'priority' and 'participation' rights, which define the venture capitalist's fixed-claim and unfixed claim with regard to firm value. A fundamental dichotomy exists, in fact, between 'non-participating' and 'participating' liquidation preferences. Non-participating liquidation preferences will eventually require that venture capitalists face a binary choice as to whether to enjoy their priority rights with regard to the value encapsulated in the liquidation preferences or their participation right and, thus, share in firm value on a merely pro rata basis. By contrast, participating liquidation preferences are such that venture capitalists will both receive the fixed amount set in the liquidation preferences and share with entrepreneurs on a pro rata basis in any additional value that may be available for distribution afterwards. See Klausner and Venuto (2013), pp 1404-1405; as well as, Maynard and Warren (2014), pp 510-523.

54 See, e.g., Bratton (2002), pp 939-940, fnn. 148-150 and corresponding text.

55 The literature has since long laid down the conceptual blocks for stressing the instrumentality of the entrepreneur-venture capitalist contract to support the efficient implementation of the contract at the venture capital fund level. It has done so by emphasizing the centrality of the fixed-term provision at the fund level in the unfolding of the entire venture capital investment lifecycle. See Black and Gilson (1998), pp 252 and 255-257; Black and Gilson (1999), p 41; and, above all, Gilson (2003), p 1091. An extensive literature emphasizes the linkage between the two set of contracts: see, e.g., Klausner and Litvak (2001), pp 2 and 15. 
deployed to informally intertwine its contents with those of the contract at the fund level, ${ }^{56}$ so that, operationally, one becomes a sort of 'extension' of the other.

Braiding ensures that the contract governing the venture capital-backed firm will support the efficient implementation of the contract relating to the venture capital fund by defining its ultimate ambitions, determining its design, and tailoring the rule governing its implementation to the firm-specific reality.

\subsubsection{Ambitions}

Braiding defines, first of all, the fundamental goal of the entrepreneur-venture capitalist contract. It deprives this contract of its own 'atomistic' existential logic, ${ }^{57}$ and substitutes it with one that conforms to the idiosyncratic timeline of the venture capital investment lifecycle.

To this end, the contractual framework governing venture capital-backed firms designs a governance model that seeks to strike a compromise between contracting parties' shared ambition for value creation and, as is consistent with the venture capital fund's timeline, the need to generate future liquidity. ${ }^{58}$ Practically speaking, this implies that the entrepreneur-venture capitalist contract typically stipulates that the venture capital-backed firm will go through two stages: a 'time to invest' devoted to value-creation and an unavoidable 'time to divest' instrumental to value-realization. ${ }^{59}$

\footnotetext{
56 On braiding in the context of the entrepreneur-venture capitalist relationship, see Gilson (2003), p 1091. As to braiding in general, see Gilson et al. (2010). In its original theorization, braiding is a contractual technology aimed to informally intertwine two contracts with a view to creating a mutual link that may support the efficient implementation of both contracts. In principle, this also holds in the context of venture capital financing: the linkage existing between the contract governing the venture capital fund and the contract governing the entrepreneur-venture capitalist relationship is in principle instrumental to that goal. This, however, implies holding the shareholder value-maximization constantly applicable throughout the entire lifetime of the entrepreneur-venture capitalist contract—which is, however, at odds, logically, with the idea of timely divestment: there cannot be a guarantee that it will be possible in practice to conjugate timely divestment and total shareholder value-maximization. See below, Sect. 3.2.2. This implies that braiding can be seen as contractual technology instrumental to solely or at least mainly supporting the efficient implementation of the contract governing the venture capital fund.

57 That is, the logic that any company as such, seen in isolation, is supposed to obey and which clearly does not reflect, in principle, the partisan interest of the decision-maker at any point in time. It has, in fact, total shareholder value maximization as its ultimate and above all constant objective: see above, nn. 6 and above all 10 .

${ }^{58}$ See, e.g., Aghion et al. (2004), pp 327-330 (emphasizing the necessarily 'temporary' nature of venture capitalists' involvement in portfolio companies and the importance of their liquidity needs in deciphering their 'behaviour' in interacting with entrepreneurs).

${ }^{59}$ See, Saez Lacave and Gutierrez (2010), p 429 (characterizing venture capital-backed firms as business propositions contemplating 'a pre-defined timeframe' and therefore 'hav[ing] a clearly specified lifetime, with times to stay and times to sell' that serve to create and realize value, respectively). See, also, Gordon Smith (2005), pp 316-318 and 337-355 (juxtaposing control rights that create a 'lock-in effect' during the first stage of the relationship where the entrepreneur tests the idea on which value-creation is contingent; and control-rights aimed at enabling the venture capitalist to pursue divestment in the second stage of the same relationship in order to liquidate the value of its shareholding). See, also, for a broader perspective, Pollman (2019), p 164 (proving receptive to this juxtaposition by noting that '[venture capital-backed firms] are aimed at eventually being acquired by another corporation or transforming to a
} 
Identifying the moment of transition from investment mode to divestment mode requires a context-specific reconstruction of the contractual contents. ${ }^{60}$ Nonetheless, as is consistent with the logic of braiding, the moment of transition most often reflects the timeline of the venture capital fund, which is relatively consistent despite the non-negligible formal variations in contractual structures observable over space and time and the great diversity of industries in which venture capitalists invest. ${ }^{61}$ Roughly speaking, the rule of thumb seems to be that the standard venture capitalist will assign the first 5 years to value creation, and the subsequent 3 years to value realization. ${ }^{62}$

\subsubsection{Design}

The logic that braiding injects into the entrepreneur-venture capitalist contract has tangible repercussions for formal contract structures: contracting parties' ambition to imprint their relationship with a biphasic structure becomes in fact particularly evident along several contractual dimensions.

A number of contractual choices are to be taken as indicators of the contracting parties' aim of value-creation. The lock-in effects associated with the choice of the corporate form provide a first, major indication of contracting parties' will to stabilize their relationship with a view to facilitating the optimal level of investment. ${ }^{63}$ The stipulation of the venture capitalist's obligation to provide further support if the firm meets the agreed-upon milestones is also instrumental for value creation in that it serves as a credible commitment that productivity will come with the reward of extended support. ${ }^{64}$ Negative covenants also indicate the venture capitalist's concern for value creation and value preservation through the right to prevent premature value realization through, for instance, asset sales that may siphon-off non-negligible fractions of value. ${ }^{65}$ The prospect of divestment also gives the entrepreneur a powerful performance incentive because he knows that, given the nature of his cash

Footnote 59 (continued)

public corporation - their existence in start-up form is understood to be ephemeral like a caterpillar in its chrysalis').

60 This would require paying attention to the terms governing both the venture capital fund, and in particular to those defining the fund's duration and investment strategy. The manner in which the same venture capitalist plans to divest, or has divested, from other portfolio companies that have received support during the same cycle of investments would also provide valuable information. The same holds with regard to general trend in the venture capital market regarding comparable deals (by industry, by product or service, and so on).

61 On this point, see Lerner and Nanda (2020), p 14.

62 Ibid.

63 See, Rock and Wachter (1999), pp 919 and 921-929 (arguing, quite famously, that close corporations, particularly high-tech start-ups, exist because of contracting parties' ambition to exploit the lock-in effect associated with the choice of the corporate form to facilitate specific investments).

${ }^{64}$ For references as to the performance-incentivizing function of staged financing and the abandonment option that it embeds, see above, n. 64.

65 On this point, see, specifically, Gordon Smith (2005), pp 346-347. For complementary insights, see also Wansley (2019), pp 154-155, fnn. 19-23 and corresponding text. 
flow-rights, his returns are contingent upon value-creation exceeding a given threshold by the time it comes around. ${ }^{66}$

Formal contract design does equally effectively support contracting parties' ambition to ensure that, as times passes, value will be realized. The entrepreneur-venture capitalist contract, in fact, assigns the venture capitalist-irrespective of whether he holds residual control or not-a variety of exit-related control-rights to pave the way for the natural metamorphosis of the venture capital-backed firm into a liquidity-generating device. These exit-related control-rights include explicit prerogatives to divest by causing the firm to go public or by consummating the redemption of his shareholding, and, most importantly, by unilaterally bringing about a trade sale. ${ }^{67}$ Although formally and operationally distinct, these exit-related control rights all seek to allow for the venture capitalist to engage in both adaptive and unilateral decision-making. ${ }^{68}$ On the one hand, they aim to ensure that the venture capitalist will be able to make the best choice of divestment technique. ${ }^{69}$ On the other hand, they aim to protect the venture capitalist's vested interest in his authority to steer the divestment process without exposing himself to potentially unfavourable interferences that may alter the distribution of value realized through divestment or even hijack the process altogether. ${ }^{70}$

\footnotetext{
${ }^{66}$ The standard view is that entrepreneurs are incentivized to create value by the prospects of regaining control following an IPO. See, Gilson (2003), pp 1091-1092 (mentioning the performance incentives that contract provides to entrepreneurs willing to create value with a view to an IPO that, following venture capitalist's divestment through a sale of his shares to the public, will return control to them). Empirical evidence seems to be at odds, however, with the control re-acquisition theory: Broughman and Fried (2020) have shown, in fact, that by the time IPOs occur most entrepreneurs have already (forcedly or voluntarily) left the firm. The case might be, then, that, rather than coming only from his ambition to regain control, the entrepreneur's incentives to create value originate from the venture capital-backed firm's financial structure and governance model (see above, nn. 48-54 and corresponding text, as well as 63-66 and corresponding text) and from the fact that, since venture capitalists' support is finite, entrepreneurs only have a correspondingly limited timespan to generate value (see above, n. 66).

${ }^{67}$ The venture capitalist's right to have his shareholding redeemed originates from so-called 'put options' (or other equivalent contractual solutions). The venture capitalist's right to cause the firm to go public stems from so-called 'registration rights'. The right to bring about a trade sale unilaterally may stem from the standard corporate contract, if the venture capitalist enjoys residual control (for instance, by causing the firm to merge with the acquirer). It can also stem from ad hoc private ordering-based solutions, such as so-called 'drag-along provisions', by virtue of which '[t]he [dragger shareholder] can force the other [shareholder(s)] to sell their shares at the same terms as that which is being sold by the dragalong right-holder. On these points, see, for varying perspectives, Basha and Walz (2002), pp 10-11; Gordon Smith (2005), pp 348-350 and 350-354; Chemla et al. (2007), pp 94-95 and 103-111; Cumming and Johan (2009), pp 380 and 421; Bienz and Walz (2010), pp 1072 and 1077-1078; Saez Lacave and Gutierrez (2010), pp 433-444. See also below, n. 81 and corresponding text.

${ }^{68}$ For input in this respect, see Bienz and Walz (2010), p 1077.

${ }^{69}$ Venture capitalists invest with an exit strategy in mind, but they cannot fully anticipate the variety of contingencies that may affect the implementation of the strategy and mandate the adaptation of the envisaged strategy to the new environment. On these issues, see Cumming and Johan (2009), pp 596-608 and 633-651 (discussing the venture capitalist's need to secure various exit-related control rights as tool to cope with unforeseeable contingencies and providing empirical data). See also, more emphatically, Gordon Smith (2005), p 339 (pointing out that venture capitalists' plans about future divestment occur in the face of uncertainty about which divestment technique 'will be optimal' from case to case).

${ }^{70}$ Intuitively, venture capitalists cannot rule out a priori that, as the time for divestment nears, entrepreneurs, perhaps tainted by self-interest, may engage in hazardously uncooperative conduct that may alter the distribution of its proceeds, ultimately complicating or even hijacking the divestment process. As to the dynamics that may unfold in the run-up to divestment, see, e.g., Saez Lacave and Gutierrez (2010), pp 433-435; and, also for some empirical data, Broughman and Fried (2010).
} 


\subsubsection{Implementation}

Not only is braiding responsible for defining the ultimate ambition and the formal design of the entrepreneur-venture capitalist contract, but it also re-shapes the rules governing its implementation so as to ensure that the venture capitalist will be able to exercise his explicit prerogatives to eventually generate timely liquidity-in any event and at any cost.

Like contracting parties in general, the entrepreneur and the venture capitalist would presumably agree to an implementation rule that commands to pursue total shareholder value. ${ }^{71}$ Yet, they would hardly choose to subject the implementation of their contract to the shareholder value maximization norm throughout its entire lifetime. This, in fact, would render braiding futile in practice, failing to account for its prevalence and ultimately jeopardising overall contractual consistency. ${ }^{72}$

In order to preserve overall contractual consistency and thereby effectively respond to the efficiency-based rationale underlying braiding, an implicit 'termination option' must, then, necessarily be embedded within the contract governing the venture capital-backed firm. This termination option vests the venture capitalist with the prerogative to carry out a timely divestment and thereby generate timely liquidity irrespective of any contingency as the venture capital-backed firm enters its divestment mode and especially as the venture capital fund nears its end. ${ }^{73}$

\footnotetext{
${ }^{71}$ For references, see above, n. 10 .

${ }^{72}$ A constant application of the shareholder value maximization alone would imply that divestment could occur only if this course of action maximizes shareholder value, thereby possibly compelling the venture capitalist to put aside his liquidity needs for an indefinite period of time each and every time divestment comes without the promise of maximizing shareholder value. This rule of contract implementation, which subordinates liquidity to value maximization, would then contradict, in these instances, the timeliness built into the logic informing the entrepreneur-contract and, along with it, the braiding strategy underlying it.

${ }^{73}$ The literature has long been inclined to stress the 'temporary nature' of the entrepreneur-venture capitalist relationship: for some references, see above, n. 30. However, the literature also seems reluctant to explicitly (and consistently) assert that the venture capitalist can have, under some circumstance, the right to terminate the firm-i.e. the right originating from the termination option theorized in the text. Notable exceptions to this general trend are Bratton (2002), p 893 (discussing the venture capitalists' option to terminate issuers that underperform); and Baird and Henderson (2008), p 1331 (noting that 'everyone begins knowing that things may not work out and the time to shut down or sell out may come'). This literature provides important input for a discussion as to the termination option theorized in the text. This literature, however, tends to anchor the termination option to the fact that, broadly speaking, the issuer underperforms, even though it also seems to implicitly postulate that this lack of convincing performance is occurring as the firm is in a late stage of its lifecycle. The termination option theorized in the text has its foundation, instead, in the evolutionary trajectory that the venture capital-backed firm typically undertakes. In some senses, it builds in line with the notation articulated by Bratton and Wachter (2013), p 1885, fn. 321 and corresponding text: '[t]he deal structure often allocates to the venture capitalist the power to detach the assets from the entrepreneur and deploy them somewhere (or with someone) else. Infinite patience is not expected from the venture capitalist-the venture capitalist has investors of its own and is under pressure to yield returns in a competitive market'. The theorization of
} 
By institutionalizing, albeit only in part, the significance of the venture capitalist' liquidity needs in the overall economy of the entrepreneur-venture capitalist business relationship, the termination option qualifies the shareholder value maximization along its diachronic dimension. It redefines the rule governing contract implementation so as to adapt it to the peculiar evolving structure of the venture capital-backed firm.

Practically speaking, it unfetters - so does the logic suggest - the venture capitalist from the exclusive end of shareholder value maximization, thereby making the room for instances of decision-making that may result in the sacrifice of a given fraction of total shareholder value. ${ }^{74}$

Despite appearances, the divestment resulting from the exercise of this implicit contractual term then represents just another discrete moment of the process of implementation of the ex ante agreed-upon bargain. And nowhere is this more manifest than in those divestment transactions that take place as the venture capital fund nears its end, making the venture capitalist's liquidity needs particularly compelling.

\section{A New View of (Some) Value-Destroying Trade Sales}

Because of braiding, the venture capital-backed firm exhibits an evolving structure that, in essence, hinges on a simple proposition prescribing that the contracting parties will seek value-creation within a given timespan. Eventually, the venture capitalist will be given free reins in realizing the value of the investments medio tempore made in the venture capital-backed firm. ${ }^{75}$

So construed, the contents of the entrepreneur-venture capitalist contract provides the key to understanding a variety of transactions instrumental to divestment, grounding an alternative and counterintuitive explanation for their possibly valuedestroying implications.

\footnotetext{
Footnote 73 (continued)

the termination option presented in the text is not meant to imply, however, that the scope of the termination option cannot be broader. Rather, that theorization is the result of the deliberate choice to point out the implications that the structure of the venture capital investment lifecycle, once put in a diachronic perspective, has on the contents of the entrepreneur-venture capitalist contract, particularly with a view to highlighting the dynamics unfolding as the venture capital fund nears its end. The claim here is that the termination option is available in these instances to cope with the venture capitalist's liquidity needs, but that this does not imply that the termination option exists only in these instances and therefore may not be available in other instances.

${ }^{74}$ In order for this termination option not to translate into the source of an arbitrary decision as to the terms of the transaction, the obligation to search for, and get, the best deal available in the M\&A market must be included in the contract, too. For input in this respect, see again Bratton and Wachter (2013), pp 1898-1900. Being concerned with the design of the fiduciary standards operating in the context of venture capital-backed firms, this aspect of the termination option is discussed more accurately in Nigro (2020).

75 See above, Sect. 2.2 and particularly Sect. 2.2.3.
} 
Although several opportunities to test this proposition may crop up as the prototypical venture capital-backed firm matures, ${ }^{76}$ the ideal experimental laboratory for appreciating the peculiar dynamic stemming from the changing structure of the venture capital-backed firm, particularly as regards the practical impact of the theorization of the venture capitalist's termination option, are so-called 'trade sales' - the liquidity event par excellence. ${ }^{77}$

\subsection{Trade Sales: Logic, Forms, Significance}

In the jargon of the high-tech entrepreneurial world, the term 'trade sales' refers, albeit non-technically, to a variety of M\&A transactions instrumental to carrying out the sale of a venture capital-backed firm. Technically speaking, trade sales are transactions whereby a third-party acquirer, generally a strategic partner, secures full control over the venture capital-backed firm's assets. By securing full control over the target's assets, the acquirer creates the preconditions for appropriating any increase in the value of the target firm in its entirety ${ }^{78}$ - to the exclusion of the otherwise free-riding pre-acquisition shareholders. ${ }^{79}$ Consistent with the ultimate aim of these transactions, cash is in principle the most appealing deal currency. ${ }^{80}$

\footnotetext{
76 Among the several possible examples, a notable one concerns the situation where the venture capitalist sells the venture capital-backed firm's assets through a piecemeal asset sale to generate a liquidity buffer that may enable him to have his shareholding redeemed with a full repayment of its value even though this may leave the entrepreneur with just a shell company. Based on the discussion articulated thus far, these events seem to call for a different assessment depending on the stage of development of the venture capital-backed firm. For a discussion, see Nigro (2020), p 5, fnn. 12-17 and corresponding text.

77 Falling under the 'liquidity events' rubric, trade sales do trigger liquidation preferences: see above, nn. 52 and 53.

78 Increases in value typically follow from the exploitation of synergies associated with the integration of the venture capital-backed firm into the group structure to which the acquirer belongs. In the case of acquisitions of venture capital-backed firms, acquirers resort to trade sales to capture the market share of a competitor and thus benefit from the ensuing reduction in competition. See Lemley and McCreary (2020), pp 21-39. Acquirers may also aim to secure the human capital behind the success of a given company rather than their physical and non-physical assets through what the literature has branded as 'acqui-hiring' transactions. For varying perspectives, see Chatterji and Patro (2014); Hussinger (2010); Coyle and Polsky (2013); and Sawicki (2015).

79 On the free-riding dynamics that emerge in this context, see, e.g., Coates IV (2018), pp 584-586; or, equivalently, Saez Lacave and Gutierrez (2010), pp 433-434.

${ }^{80}$ M\&A transactions can feature a variety of types of 'currencies' (i.e., types of consideration): Acquirers can pay the bidder (or its shareholders) through cash, their own shares, or a mix of the two. See, e.g., Coates IV (2018), p 575. Despite the potential variety of deal currencies available, acquirers aiming to appropriate any increase in the value of the target firm in its entirety cannot help but secure all the equity securities issued by the target itself, which 'compels' them to resort to cash as the deal currency. However, this is not always the case for a variety of reasons (e.g., taxation; also, entrepreneurs sometimes receive a vested equity interest in the acquiring firm to facilitate the 'know-how' transfer: see Braun et al. (2020), p 4).
} 
Trade sales, at least in theory, come in a number of functionally equivalent transactional forms - namely, asset sales, asset combinations, and share transfers. ${ }^{81}$ While functionally equivalent, the economics of these transactions partly differ because of their varying mechanics. Asset sales, for instance, typically feature higher transaction costs and an inherent inability to enable the seller to capitalize on the 'organizational component' of the target firm. ${ }^{82}$ From the perspective of the shareholders on the sell-side and particularly the venture capitalist, asset sales may therefore be less appealing than, say, asset combinations. Deal-specific contingencies or institutional variables may restrict some further the menu of available options. For instance, only venture capitalists who enjoy residual control over the firm will be able to steer decision-making at both the board and the shareholder levels and will thus be able to consummate a trade sale in the form of an asset combination (i.e., a merger or other equivalent transactional scheme). ${ }^{83}$ Venture capitalists who lack residual control and are therefore unable to achieve that goal by causing the firm to take that action may instead need to resort to the corporate contract in order to receive the prerogative to bring about a trade sale unilaterally by dragging the entrepreneur's shareholding along with their own in a so-called 'compelled share co-transfer' ${ }^{84}$ Regulatory limitations regarding cash as the deal currency available in the event of asset combinations may also exist, ${ }^{85}$ inducing contracting parties to resort, once again, to private

\footnotetext{
${ }_{81}$ On functional equivalence, see, Coates IV (2018), pp 572-573. See also, more extensively, Black and Gilson (1995), pp 639-729; and, more recently, Kershaw (2016), pp 31-64. These transactions are functionally equivalent from the perspective of both the target and the acquirer. From the target shareholders' point of view, they are the function of the power to transfer full control. It has an obvious economic justification, namely, to prevent any hold-up that may result in value-redistribution. See Coates IV (2018), pp 584-586 (for rationale of the statutory power to cause asset combination); Saez Lacave and Gutierrez (2010), pp 433-434 (for the rationale of the private ordering-based device granting one shareholder the power to co-sell the other shareholder's shareholding in the firm-i.e., drag-along provisions); and Goshen and Hamdani (2015), p 614, fn. 169 and corresponding text (for input to appreciate the functional equivalence of these two techniques, and their 'parenthood' with asset sales through firm dissolution and liquidation). From the acquirer's point of view, they are-as noted earlier in the text (see above, nn. 78-79) - instrumental to prevent free-riding by pre-transaction shareholders. The discussion articulated herein considers only the most basic forms in which trade sales can come. Other transactional schemes that are functionally equivalent to those considered in the text are certainly available. See, for instance, Davies (2016), pp 16, fn. 47 (discussing compelled share co-transfers based on drag-along provisions as an alternative to mechanisms whereby a shareholder who has acquired a controlling shareholding at a given price per share can get rid of non-controlling shareholders by compelling them to sell out their shareholding at the same pro rata price (so-called squeeze-out rights)). For the purposes of this discussion, in addition to the assumption that the entrepreneur and the venture capitalist are the sole investors in the firm (see above, n. 10), the assumption is also made that the various transactional forms in which trade sales come are subjected to negligibly different tax regimes. These assumptions are necessary to avoid complicating the analysis and ultimately preserve the unity of the conceptual discussion that this piece of research aims to deliver.

${ }^{82}$ Contracts, for instance, must specify each asset being sold. See, e.g., Kershaw (2016), p 32.

${ }^{83}$ Broadly speaking, these transactions postulate approval at the shareholder level, as well as sometimes approval at the board level. For a general discussion, see, e.g., Coates IV (2018), pp 577-578 and 588590.

${ }^{84}$ Compelled share co-transfers are a function of the authority that the venture capitalist receives from drag-along provisions. See above, nn. 67 and 81.

${ }^{85}$ In Europe, for instance, cash-for-stock mergers are not allowed. For details, see, Nigro (2019), p 288, fn. 635 .
} 
ordering-based solutions in order to pave the way to other transactional schemes-in this case also in the form of compelled share co-transfers.

The economic importance of trade sales as a divestment technique for the venture capitalist is nowadays well established. In fact, although IPOs have long been considered the golden divestment technique for venture capitalists, ${ }^{86}$ a different view has recently gained traction acknowledging that trade sales are actually much more common than IPOs and, in the aggregate, just as important. ${ }^{87}$ The reasons behind venture capitalists' reported increasing 'preference' for trade sales over IPOs, at least in recent times, are various. Trade sales may enable the venture capitalist to cash-in his investments more quickly than IPOs, to capture a fraction of the value that the acquirer transfers to the target in order to consolidate his market share by reducing competition. ${ }^{88}$ Also, they may enable the venture capitalist to benefit in price-setting from the more accurate mechanisms operating in the M\&A market relative to those in the IPO market, or to benefit from sparing the costs associated with the process of going-public. ${ }^{89}$

\subsection{Unavoidable Value-Destroying Trade Sales: Definition and Underlying Dynamics}

The newfound importance of trade sales as a divestment channel has led to a significant increase in interest from academics-particularly legal scholars-in recent times. Attention has mostly been directed towards mapping the variety of conflicts of interests plaguing trade sales and singling out the instances of opportunistic decision-making that can lead to value-destruction through these transactions. ${ }^{90}$

\footnotetext{
${ }_{86}$ This is a commonplace assertion in the literature. See, Cumming and Johan (2009), p 372; and Sahlman (1990) (both documenting that almost all returns for investors in venture capital funds come from IPOs). This assertion seems to find its root in two oft-cited strands of literature. One portrays IPOs as the best means available for venture capitalists to signal their performance to the market (particularly for the purposes of so-called 'grandstanding strategies'-i.e., younger venture capital firms' strategies to build a good reputation by 'showing-off' their skills through divestment: see, Gompers (1996), pp 135-136). Another theorizes IPO's importance for entrepreneurs based on the 'control-reacquisition theory', which a very recent literature has called into question. See above, n. 66 .

${ }^{87}$ EU-based venture capitalists have always tended to divest through trade sales more than through IPOs, whilst US venture capitalists have been increasingly opting for similar solutions in recent years. As to the EU, see, chiefly, Bienz and Walz (2010), p 1072. As to the US, see Broughman and Fried (2013), p 1322, fn. 11 and corresponding text (highlighting the increased importance of trade sales in the US context); and Gao et al. (2013), pp 1672-1673 (providing data as to changes in the trends observable within the US market from 2001 onwards).

${ }^{88}$ On these points, see, at length, Lemley and McCreary (2020), pp 21-39.

${ }^{89}$ Ibid.

${ }^{90}$ Quite an extensive literature deals with entrepreneur-venture capitalist conflicts of interests, as well as venture capitalist-venture capitalist conflicts of interests that may emerge in the run-up to trade sales and during their consummation. To name a few, see, for varying perspectives, Fried and Ganor (2006), pp 993-999; Broughman and Fried (2010), pp 386-287; Broughman and Fried (2013), pp 1331-1335; Klausner and Venuto (2013), pp 1403-1418; Bratton and Wachter (2013), pp 1874-1900; Strine (2013), pp 2027-2039; Wansley (2019), pp 168-179; Korsmo (2013); Katz (2019). See, also, Baird and Henderson (2008), pp 1328-1333. This literature provides input on the value-destroying trade sales-related discussion from the perspectives of US corporate law, but nonetheless it sheds light on the underlying economic dynamics. As noted earlier (see above, nn. 7-11 and corresponding text), most studies have
} 
The centre of the debate has been, in particular, premature opportunistic valuedestroying trade sales consummated by the venture capitalist. ${ }^{91}$ The discussion has only recently begun to (vaguely) include the scenario in which the venture capitalist sells 'in the vicinity of the venture capital fund's end'. 92

The focus here is precisely on the undertheorized unavoidable value-destroying trade sales that the venture capitalist may consummate as the venture capital-backed firm enters into its divestment mode and particulalry as the venture capital fund's end approaches. These transactions are (1) unavoidable because they respond to the compelling need of the venture capitalist to carry out a timely divestment and, hence, generate timely liquidity. Additionally, as they are unavoidable and thus not deferrable, these transactions (2) may be value-destroying because of the contingencies affecting the process required to generate value through M\&A transactions during the time-window in which these transactions need to be necessarily executed.

M\&A transactions do generally succeed at generating value for target shareholders, ${ }^{93}$ provided, broadly speaking, that some crucial factors exist. First and foremost, the M\&A market must be inclined to assign valuations to a given firm that exceed firm value. Second, the seller must be in a good enough bargaining position to capture a given fraction of the additional value that the transaction can generate. The seller's right to reject an offer and come back to the market at a more opportune time generally provides in any event (provided that no disturbing factor, such as conflicts of interests, alters the decision-making process) a relatively strong defence against value-destruction. ${ }^{94}$

\footnotetext{
Footnote 90 (continued)

discussed-primarily or even exclusively-how conflicts of interest may lead venture capitalists to engage in opportunistic decision-making. More recently, however, the conflicts of interest that may lead entrepreneurs in control to accept low-ball offers to the detriment of total shareholder value have also attracted scholarly attention. See, in particular, Wansley (2019) (providing an extensive discussion of the so-called 'beach-money problem', which results when entrepreneurs in control to divest prematurely to capture a payoff that, though large enough to give them the metaphorical luxury of a life on the beach, represents little money for venture capitalists with more serious aspirations to go for 'big ticket-exits').

${ }^{91}$ See, again, Fried and Ganor (2006).

92 It seems that the discussion articulated in Bratton and Wachter (2013), pp 1882-1900 builds on the consideration of this specific scenario.

${ }^{93}$ See, by way of introduction, DePamphilis (2014), p 29 (reporting average abnormal returns during the 2000 s as compared to $18.5 \%$ during the $1990 \mathrm{~s}$ ).

${ }^{94}$ On these points, for a mainly theoretical discussion, see DePamphilis (2014), pp 115-184.
} 
Enjoying flexibility in timing M\&A transactions appropriately is accordingly crucial for prospective sellers to effectively engage with the market and deal with prospective buyers. The venture capitalist approaching the market to carry out an unavoidable trade sale does not always have this flexibility, though.

\subsubsection{Unavoidability}

Venture capital is a time-sensitive business. ${ }^{95}$ Although it may sometimes be possible for the venture capitalist to buy some additional time from his own investors, ${ }^{96}$ this is a stopgap at best. Divestment is an inevitable fact of life for a venture capitalbacked firm, and, in spite of extensive contractual pre-planning, ${ }^{97}$ trade sales often emerge as the best or even the de facto only available option to generate the liquidity that the venture capitalist urgently needs as the time to divest approaches. ${ }^{98}$

In a manner similar to a mandatory go-shop provision contingent upon a future event, the prospects of having to pay back his own investors on time urges the venture capitalist to shop the firm immediately, rendering these transactions practically undeferrable.

\footnotetext{
95 See above, nn. 30 and, more broadly speaking, nn. 31-43 and corresponding text.

${ }^{96}$ I.e., if the contract with the fund investors contemplates this possibility and investors in the fund give their consent, the fund's lifetime can be extended and, with it, possibly the support that venture capitalists give to portfolio firms too: see above, n. 31 .

${ }^{97}$ See above, nn. 67-70 and corresponding text.

${ }^{98}$ IPOs are not always the best way to realize investments- that is, they may generate lesser total shareholder value than a trade sale. Moreover, they may sometimes be practically unviable due to various reasons ranging from the 'unripe' state of the business project to the length of the process of going public. A redemption of the venture capitalist's shareholding may be impossible because venture capital-backed firms often have limited operating liquidity, which is generally insufficient to fund the redemption of venture capitalists' shareholdings. True, the venture capitalist could manoeuvre these firms to sell their 'crown jewels' and generate a cash buffer, but even when firm value does not primarily reside in the organizational bond tying the firm together, this strategy may only generate modest liquidity. The venture capitalist would then plausibly receive less than what he would get if he could capitalize on the company as a whole. More importantly, share redemption could even lead to bankruptcy, which would destroy an additional fraction of firm value and thus prove unlikely to leave the entrepreneur better off than he would be if the venture capitalist were to choose a different divestment strategy. For additional information, see Nigro (2019), pp 332-335 and Nigro (2020), pp 18-21.
} 


\subsubsection{Value-Destroying Potential}

The unavoidable nature of these trade sales can have drastic implications for value creation. In a manner similar to so-called 'fire sales, ${ }^{99}$ trade sales can in fact eventually fail to realize full firm value. ${ }^{100}$

This can be attributable, broadly speaking, to two partly correlated factors with which the venture capitalist has possibly or necessarily to deal: a transiently unfavourable M\&A market and a weak bargaining position.

3.2.2.1 An Unfavourable M\&A Market To begin, the venture capitalist may have to carry out an unavoidable trade sale in an unfavourable M\&A market. Although valuations in the M\&A market certainly tend to approximate firm value in the long-run, ${ }^{101}$ temporary situations can emerge in which valuations in the M\&A market stand more or less significantly below firm value.

Various inefficiencies may be responsible for this fact. First, the M\&A market may be going through a 'cold' phase because of an adverse macro-economic conjuncture. During a recession, steep declines in consumption levels can cause decreases in firm turnarounds, which may in turn lead more firms to generate liquidity by selling their assets. On the other hand, cash shortages and uncertain macroeconomic prospects may actually induce other firms to reconsider their investment and expansion plans and hence their ambitions to pursue external growth

\footnotetext{
99 Unavoidable trade sales are reminiscent of so-called 'fire sales'. The literature portrays fire sales as forced sales of assets at a dislocated price. The sale is forced because the seller needs to generate liquidity to satisfy creditors or, more broadly speaking, to meet other cash shortfalls. The price is dislocated because not all potential buyers are in a position to bid for the asset and the transaction cannot be postponed until a higher price can be achieved. See, Shleifer and Vishny (2011), p 30; and Meier and Servaes (2019), p 4229. Unavoidable trade sales seem to be a close relative of fire sales. In both scenarios, decision-making on the sell-side must face the effects of constraints that are the function of compelling liquidity needs that may stand in the way of realizing in full the value of the assets being sold. Nonetheless, there are differences. One difference seems to lie in the fact that in modelling fire sales the finance literature refers such liquidity needs to the seller as such, whereas in unavoidable trade sales they obviously concern one shareholder-namely, the venture capitalist. Indeed, as the contractual framework governing venture capital-backed firms institutionalizes the significance of the venture capitalist's liquidity needs by imprinting the firm with its particular bi-phasic structure, this difference seems to be of relative importance-or, to be sure, seems to be more apparent than real. In fact, building on a contractarian view of the firm, the claim can be made that the venture capitalist's termination option implies that his liquidity needs are also a component of the ultimate purpose of the venture capital firm.

100 Firm value and the value that the firm has on the M\&A market are clearly interconnected: firm value also reflects the value that can be generated by selling the firm. Accordingly, positive or negative fluctuations of the value of the firm on the M\&A market can affect firm value. Yet, not only do these two figures not overlap but they are conceptually quite distinct. Above all, for the purposes of this discussion, though by way of simplification, they are kept completely distinct. To be sure, consistent with the lesson of corporate finance, firm value is defined as the sum of an appropriately discounted stream of cash flows for a given timespan. See DePamphilis (2014), pp 217-376. Market value is, instead, the value that can be realized on the M\&A market by selling the firm.

101 See, for instance, Shleifer and Vishny (2003) (assuming in their analysis that, although acquirers' valuations may be influenced by market sentiment in the short run, they tend to converge to the 'true' value in the long run, instead).
} 
strategies. ${ }^{102}$ Under such circumstances, it may prove impossible to resort to M\&A transactions to realize firm value in full. ${ }^{103}$

Second, competition on the buy-side may be temporarily 'frozen'. Most assets exhibit a high degree of specialization. Accordingly, only a limited number of firms endowed with appropriate 'absorptive capacity' can profitably redeploy them. ${ }^{104}$ To the extent that the most attractive strategic partners are temporarily unable or unwilling to invest money in the acquisition of some of these highly specialized assets, they would then need to be sold to industry outsiders who, due to their inability to use them to their fullest potential, would pay less than their full value. ${ }^{105}$

3.2.2.2 A Weaker Bargaining Position A seller who needs to sell now rather than tomorrow suffers from a competitive disadvantage. Empirical evidence confirms it, though indirectly. ${ }^{106}$ The reason is straightforward: Prospective acquirers know that the seller does not have a 'no-deal option' at his disposal and that, accordingly, a sale at a price that neither includes a premium nor reflects the asset value in full is a superior option to a no-sale. Prospective acquirers can therefore exploit the uneven allocation of bargaining power resulting from the constraints affecting their counterparties to extract more favourable terms. Obviously, adverse conditions in the market may reinforce the effects of such uneven allocation of bargaining power- to the further benefit of prospective acquirers.

The market frictions described above can materialize during the time-window within which the venture capitalist must consummate an unavoidable trade sale. Venture capital-backed firms that are involved in unavoidable trade sales may accordingly have a difficult time attracting acquisition offers that incorporate a

\footnotetext{
102 Periods of high- or low-market sentiment, unrelated to actual shifts in fundamentals and thus profitability, may influence the frequency of M\&A transactions and the valuations at which they occur, giving rise, for instance, to the phenomenon of so-called 'merger waves' (on which see Duchin and Schmidt (2013)), during which generally the M\&A market expresses higher valuations.

${ }^{103}$ This argument replicates, in view of the M\&A market, the theory presented by Shleifer and Vishny (1992) to account for the general equilibrium of asset sales (a locution here clearly referring to transactions instrumental to sale assets and, thus, more inclusive than it may suggest ictu oculi). In the context of a market affected by an industry- or economy-wide shock, sellers may have to face the fact that ideal intra-industry buyers are also affected by the shock and thus unable to buy the assets. These assets would then need to be sold to industry outsiders who, for a variety of reasons, would not value these assets accurately and would then pay less than their 'real' value.

104 Absorptive capacity is a firm's ability to recognize the value of new information, assimilate it, and apply it to commercial ends. See, Cohen and Levinthal (1990).

${ }^{105}$ An extensive literature deals with the consequences of asset specificity and the ensuing limited ability to redeploy them. Kim (2018), for instance, provides empirical confirmation of the negative correlation between asset specificity and firm value in mergers (particularly but not exclusively if the seller is financially constrained). To the extent that limited asset redeployability affects competition on the buyside, a depression of valuations may ensue. For example, Gorbenko and Malenko (2018) show that a temporary tightening of acquirers' financial constraints may lower bidders' incentives to approach a target, reducing competition and, thus the acquisition prices.

${ }^{106}$ Reference is made, again, to the literature on fire sales. Recent research has shown that, because of their liquidity constraints and their compelling need to sell now rather than tomorrow sellers in fire sales are in a weaker bargaining position. Buyers can exploit this situation to their own advantage, causing a transfer of wealth from sellers. See, again, Meier and Servaes (2019), pp 4243-4248.
} 
premium or even approximate firm value. Moreover, for a venture capitalist who is approaching the market under the liquidity pressure stemming from his time-sensitive business model, the need for deal completion outstrips the ambition for deal optimization.

Although the M\&A market may provide solutions, these are occasional and not completely effective. ${ }^{107}$ The combinations of market frictions and diminished bargaining power can, alternatively or cumulatively, effectively account-as the literature on fire sales indirectly confirms ${ }^{108}$ — for the temporary impossibility of realizing firm value in full on the M\&A market. The discount that the acquirer has managed to secure stands as a proxy for the ensuing value-destruction.

In principle, any venture capital-backed firm is a potentially suitable 'victim' of these transactions. However, speculation would suggest that unavoidable value-destroying trade sales can concern particularly those venture capital-backed firms that, while staying afloat quite well, exhibit only slow and modest growth. ${ }^{109}$ Perhaps allured by the prospects that the firm may successfully implement a 'pivot', ${ }^{110}$ the venture capitalist may be tempted to adopt a 'wait-and-see' strategy that could eventually lead him to delay divestment beyond the optimal moment. Besides, the limited growth potential may imply that these venture capital-backed firms attract only a few prospective buyers, leading, to the extent that this is the case, to suboptimal levels of competition-with all the ensuing consequences, given also the weak bargaining position of the selling venture capitalist, on the chances for value-creation or, conversely, value-destruction. ${ }^{111}$

Whichever the driver behind the value-destruction associated with unavoidable value-destroying trade sales, their ultimate outcome is poised to generate harmful consequences sometimes only for the entrepreneur and sometimes also for the venture capitalist ${ }^{112}$ — with correspondingly different implications given their differing exposures to firm risk. ${ }^{113}$

\footnotetext{
107 Venture capital and private equity funds are, to some extent, active in the M\&A market as 'secondary buyers'. For a discussion (as regards the US experience), see Ibrahim (2012). This market-based solution suffers from two main limitations. First, it is only occasionally available. Therefore, a market for 'secondary investments' is not always operating. Second, there is no reason to think that these secondary buyers would be necessarily able or willing to pay more than any other prospective acquirer (regardless of market conditions).

${ }^{108}$ For references, see above, n. 99.

109 That is, unavoidable value-destroying trade sales may actually concern in particular sideways firms, which generally are the majority of the venture capital-backed firms in a given portfolio according to the literature reporting industry trends: see, above, n. 36.

110 'To pivot' in the world of high-tech firms and particularly venture capital-backed firms refers to the decision to shift towards an entirely new strategy and it often entails drastically changing the whole company. Cases exist, however, where a pivot requires changing one aspect of the business (e.g., by turning one feature of a product into the product itself, with a view to delivering to the market a product based on a more streamlined concept).

${ }^{111}$ See above, Sect. 3.2.2.2.

112 The typical financial structure of the venture capital-backed firm is such that the entrepreneurial risk is allocated unevenly. See above, n. 53 and corresponding text. Firm value can be therefore allocated correspondingly unevenly, for instance through trade sales. For a simple but useful example, see below, Sect. 4.3, particularly nn. 154-156 and corresponding text.

113 The entrepreneur and the venture capitalist, given their different levels of investment diversification, are exposed to the firm-specific risk in different manners. See above, n. 25.
} 


\subsection{A More Thorough Assessment}

At first glance, unavoidable value-destroying trade sales are all simply value-destroying trade sales: that is, they all are merely transactions that negatively affect total shareholder value. As such, unavoidable value-destroying trade sales may apparently have a somewhat 'opportunistic aftertaste'. A combination of three elements may contribute to this potential perception. One element is general and it concerns the link between opportunism and value destruction. In the common discourse, valuedestruction (if not stemming directly from bad luck) is often associated with opportunistic decision-making. ${ }^{114}$ As contracts are value-maximizing devices, the idea that a contract can contemplate instances of decision-making that may lead to valuedestruction sounds puzzling, to say the least. Another element concerns the connection between opportunism and unavoidable value destroying trade sales. It is not rare for the venture capitalist to exit earlier than his contract suggests, sacrificing total shareholder value solely to his own advantage and to the detriment of the entrepreneur. ${ }^{115} \mathrm{~A}$ further element originates from the unequal impact that unavoidable valued-destroying trade sales may have on the wealth of the entrepreneur and the venture capitalist, ${ }^{116}$ with the venture capitalist possibly being able to maximize his wealth through these transactions. ${ }^{117}$

Unavoidable value-destroying trade sales are therefore tendentially grouped into the generic category of those transactions that venture capitalists carry out well before the potential of their portfolio companies has been fully realized. ${ }^{118}$ While describing the existing reality, this categorization rests on the observation of extrinsically identical outcomes, but it neglects to look deeper into the different drivers behind them.

A holistic assessment that factors in the peculiar contents of the entrepreneur-venture capitalist contract does reveal, however, a different reality. The contract governing venture capital-backed firms seeks to balance value creation and the venture capitalists' future liquidity needs, exhibiting a formal design and obeying an implementation rule that vindicate this ambition. ${ }^{119}$ Under this contractual framework, the venture capitalist has the authority to carry out the timely divestment required to generate the timely liquidity needed to support the efficient implementation of the contract at the fund level and, hence, create the preconditions for his

\footnotetext{
114 For instance, in discussing misappropriation by a fiduciary, Cooter and Freedman (1991), pp 10481051 bring in a binary explanation: bad luck or opportunism.

115 Reference is made to the premature value-destroying trade sales mentioned in the opening of the article: see, also for references, above, n. 9-11 and corresponding text.

116 See above, n. 112 and corresponding text.

117 For a simple but useful example, see, again, below, Sect. 4.2, especially nn. 154-156 and corresponding text.

118 See Lerner and Nanda (2020), p 8 (noting that the time constraints affecting the venture capital business model lead to situations in which such investors often exit their investments well before growth opportunities are fully realized').

119 See above, Sect. 2.2.
} 
self-perpetuation: the termination option. ${ }^{120}$ Unavoidable value-destroying trade sale are the most tangible manifestations of the venture capitalist's decision to avail himself of this termination option.

As such, in spite of their appearance and even the fact that value-destruction may sometimes affect only the entrepreneur, ${ }^{121}$ unavoidable value-destroying trade sales do never contradict the contract governing the venture capital-backed firm. To the contrary, unavoidable value-destroying trade sales are just another moment of the process devoted to implement the terms of the agreed-upon bargain, regardless of how the value that these transactions generate is allocated between the entrepreneur and the venture capitalist.

\section{The Standard Corporate Contract's Response}

In its ambition to imprint the venture capital-backed firm with its biphasic structure, the contractual framework governing the entrepreneur-venture capitalist business relationship assigns the venture capitalist the authority, at a given point in time, to cause liquidity-generating events irrespective of any contingency. The most manifest manifestation of the venture capitalist's decision to exercise this termination option are unavoidable value-destroying trade sales.

These partial conclusions prelude to a crucial question that pertains the ways in which the standard corporate contract deals with the dynamics stemming from the contractual arrangements that are typical of venture capital-backed firms and, in particular, with the venture capitalist's termination option. The question is, more precisely, as follows: how does the standard corporate contract 'intercepts', and 'reacts' to, unavoidable value-destroying trade sales?

Answering this question requires an incursion into its inner logic and, above all, into its basic contents. ${ }^{122}$

\footnotetext{
120 See above, Sect. 2.2.3.

121 See, again, above, n 112 and corresponding text.

122 To be sure, venture capital-backed firms are private firms. As such, they are not subject to the regime governing public corporations. Broadly speaking, this implies that the standard corporate contract exhibits a lesser degree of complexity, particularly as regards the variety of techniques to which it typically resorts to address value-destruction in some contexts. This means, inter alia, that the number of techniques to which the standard corporate contract resorts in order to support the quest for value-maximization is more limited. To make sure that the firm involved in some fundamental transactions is valued accurately and objectively, the standard corporate contract sometimes mandates that its value must be determined by specialized appraisers (generally investment banks releasing so-called 'fairness opinions'). Fairness opinions, for instance, are generally not required for private firms that are the subject of fundamental transactions. To the extent that corporate law (even if just 'in action' rather than 'on the books') makes any additional techniques available for the entrepreneur, the discussion articulated herein would possibly also concern, mutatis mutandis, these additional techniques, too. This would be the case, for instance, for the fairness opinion that some commentators have advocated to counteract the problems associated with an 'unfair' valuation of the entrepreneur whose shareholding is 'dragged-along' with that of the venture capitalist (for some hints, see, e.g., Priester (2010), p 1140), even though only to the extent that the recommendation to resort to such protection were to be affirmed by a court and, above all, only if fairness in this context were not to be determined based solely on the valuation of the firm in the M\&A market.
} 


\section{Fair Value Protections}

The standard corporate contract is written with ordinary firms in mind-firms that, whether held widely or closely, are supposed to operate for an indefinite period of time with a view to constantly maximizing the wealth of their participants throughout their entire lifetime. ${ }^{123}$ Consistent with this general idea of firm reality, the standard corporate contract makes total shareholder value its ultimate and, above all, diachronically constant objective. ${ }^{124}$

To facilitate the achievement of this objective, it first lays down the fundamental institutions required for the decision-making process to unfold. ${ }^{125}$ However, taking - inter alia - the potential corruptive influence of the personal interests of decision-makers into consideration, it also seeks to protect shareholders external to the decision-making process ${ }^{126}$ from harmful decisions by formalizing a variety of safeguards and remedies to neutralize the consequences of potential malfeasance. ${ }^{127}$

Among these safeguards and remedies are-inter alia ${ }^{128}$ - fair value protections. Fair value protections entitle shareholders external to decision-making to receive the pre-transaction value of their shares vis-à-vis a given list of actually or potentially value-destroying transactions singled out for their potential or even likely harmfulness, so as to eventually escape their consequences. ${ }^{129}$ The pre-transaction value of the shareholding is commonly referred to as 'fair value' and consists in the pro rata share of firm value. ${ }^{130}$

\footnotetext{
${ }^{123}$ For inputs in this respect, see the extensive discussion articulated by both Pollman (2019) and, earlier in time, Bartlett III (2006).

${ }^{124}$ See above, n. 10.

125 See Armour et al. (2017a), p 1-4 (discussing briefly the organizational effects of the corporate contract).

${ }^{126}$ For the meaning of this locution see above, n. 11 and corresponding text, as well as nn. 8 and $83-85$ and corresponding text.

127 The standard corporate contract is designed with the aim of 'reducing the ongoing costs of organizing business through the corporate form [...] by facilitating coordination between participants in the corporate enterprise, and by reducing the scope for value-reducing forms of opportunism among different constituencies'. See Armour et al. (2017a), p 2.

${ }^{128}$ Another commonly deployed technique are fiduciary standards, which, however, fall outside the scope of this discussion. See, also for references, above, n. 18 and corresponding text.

129 Fair value protections play a pervasive role in contemporary corporate law and, at least some forms, are the important example of the rules of the corporate contract terms setting the 'rules of divestment' (i.e., defining the 'exit strategy' for shareholders external to decision-making). See, Armour et al. (2017b), p 34. See also, Rock et al. (2017), p 186, fn. 99 and corresponding text; and, more extensively, Fischel (1983). From a similarly functional perspective, but with regard to close corporations only, see, Roth and Kindler (2013), p 120 and, more extensively, 143-146 (portraying the right to divest at fair value as a fundamental protection for shareholders external to decision-making). For the sake of clarity: the focus herein is on fair value protection as a tool to protect individual prerogatives, but fair value protections also collaterally protect shareholders as a class by making unpopular decisions more expensive for the company to pursue.

${ }^{130}$ For a lucid explanation of the economics of fair value protections see, Margolin and Kursh (2005). To be sure, this scholarship uses the locution going-concern value, which, indeed, is not another standard of value, but just an assumption as to the operational status of the business-i.e., about the fact that is not being liquidated, but keeps running - on which the actual application of the standards of value of common use builds. See, at length, Pratt (1989), p 10.
} 
Their fundamental logic is simple: they define firm value as the floor for the price that decision-makers can negotiate in a variety of transactions and, thus, for the price of each shareholding in that firm. ${ }^{131}$ Accordingly, if decision-makers sell the firm for a price that falls below this floor, aggrieved shareholders external to decision-making will have incentives to activate these fair value protections to neutralize the attempted predation.

In principle, fair value protections are available in connection with fundamental transactions that occur at the corporate level such as asset combinations (e.g., mergers). ${ }^{132}$ To the extent that the standard corporate contract treats asset sales like fundamental transactions, they can also trigger fair value protections. ${ }^{133}$ The tendential correlation between fair value protections and the fundamental transactions that unfold at the corporate level does not imply that they cannot be made available for functionally equivalent transactions that unfold at the shareholder level such as compelled share co-transfers. ${ }^{134}$

Fair value protections can exhibit different designs. One option is to grant shareholders external to decision-making a put-option against the company with a strike price set by reference to firm value. ${ }^{135}$ A second option is to empower shareholders to sue the company for damages, which can amount to a sum equal to the difference between the fair value of their shareholdings and the post-transaction value that shareholders actually received. ${ }^{136}$ A third option is to bring in an ex ante safeguard setting an explicit minimum price at which decision-makers can sell external

\footnotetext{
131 This theorization (indeed elaborated with regard to one specific fair value protection-namely, US appraisal rights) does famously comes from Fischel (1983), p 879, fn. 15 and corresponding text. See, however, also Kanda and Levmore (1985).

132 See Rock et al. (2017), pp 183-199.

133 For details and an example (under Italian corporate law), see Giudici et al. (2020), p 13.

134 In Italy, for instance, a shareholder whose shareholding is dragged-along by another shareholder in a compelled share co-transfer has the right to receive at least the fair value of his shareholding. This regime is the result of a case-law subjecting the enforceability of drag-along provisions to the mandatory provision of a floor that must refer to the statutory criteria for the determination of fair value in the event in which the shareholder avails himself of diritto di recesso. For details, see Nigro and Maltese (2020), pp 11-18 and Giudici et al. (2020), pp 9-11.

135 Thereby 'allowing dissatisfied shareholders to escape the financial effects of organic changes approved by shareholder majorities by selling their shares back to the corporation at a 'reasonable' price in certain circumstances': Rock et al. (2017), p 186, fn. 95 and corresponding text.

136 No difference is apparent on a conceptual level, at least for the purposes of this discussion, between the following two options. One consists in providing shareholders external to decision-making with the right to obtain the difference between the pre-transaction and post-transaction values of their shareholdings. Another consists in assigning shareholders external to decision-making the right to sell their shareholdings back to the firm at the pre-transaction value to avoid bearing the decrease in value resulting from the same transaction. Either way, shareholders external to decision-making receive fair value for their shareholdings. See, again, Rock et al. (2017), p 187, fn. 105 and corresponding text.
} 
shareholders' holdings as long as the corporate contract vests them with the authority to do so. ${ }^{137}$ The price can be set, once again, in reference to firm value. ${ }^{138}$

Fair value protections may also differ along another significant dimension: the criteria according to which the firm value and, thus, the fair value of a given interest in it is determined. Firm value can theoretically be determined by resorting to a variety of methodologies reflecting, inter alia, the discounted value of the firm's cash flow, and/or the value of its assets, and/or its market capitalization. ${ }^{139}$ The standard corporate contract can take different stances with regard to how firm value and, hence, fair value should be determined. Among the options available, four are of significance here. A first option is to bring in a fair value protection that vests shareholders external to decision-making with the right to claim the fair value of their shareholdings without any further specification as to which methodology is to be deployed for its quantification, leaving it open for an ex post specification. ${ }^{140} \mathrm{~A}$ second option is to mould fair value protections by delegating contracting parties to choose the methodologies that they find to be the most appropriate, but requiring them to write down these criteria ex ante. ${ }^{141} \mathrm{~A}$ third option is to shape a fair value protection in terms of the methodology to be deployed to determine firm value by specifying through mandatory legal terms the criteria to be applied for an estimate of the value of the firm and, therefore, the fair value of a particular shareholding. ${ }^{142}$ A fourth option is to bring in a fair value protection and allow contracting parties to specify the criteria and/or methodologies relevant for the determination of fair value while simultaneously resorting to more or less stringent criteria by setting a 'floor'-i.e., a minimum price that shareholders claiming fair value have the right to receive 'in any event'. ${ }^{143}$

\footnotetext{
137 The corporate contract can do so for instance by way of drag-along provisions: see above, chiefly nn. 67 as well as $84-85$.

138 The notations in the text require making a precise specification explicit. Depending on fair value protections' design, the burden stemming from their activation may either fall on the company and, thus, on its acquirer, or on the decision-maker, whether that be the shareholder as such or the company itself. For the purposes of this discussion, however, this specific aspect of fair value protection can be ignored. Fair value protections will all be treated as if the burden of disbursement were to fall on the decision-maker.

139 For a non-technical introduction to valuation methodologies, see Pratt (1989). For a more technical discussion, see instead DePamphilis (2014), pp 259-298.

140 The most immediate example is provided by Sect. 262 of the Delaware General Corporate Law, which grants shareholders dissenting from a variety of transactions (such as mergers) the well-known appraisal right. For details, see, e.g., Clark (1986), pp 443-457 and Bainbridge (2012), pp 97-111.

${ }^{141}$ This solution is compatible with the design of, for instance, US appraisal rights, for references on which see above, n. 140.

${ }^{142}$ Under Italian corporate law, for instance, the law explicitly brings in the criteria that must be applied to determine fair value: see Arts. 2437-ter and 2473 c.c. According to many commentators (and above all according to courts), these criteria cannot be departed from. For details, see Nigro and Maltese (2020), pp 11-13; and Giudici et al. (2020), pp 9-12.

${ }^{143}$ That is, regardless of the value that would result by applying other criteria and/or methodologies.
} 
While choices as to these aspects of fair value protections' design may vary due to variations (chiefly) in policy choices, ${ }^{144}$ fair value protections do typically all exhibit one common and constant operational feature. They are the function of bright-line rules of the corporate contract that enable the aggrieved shareholder to claim the fair value of his shareholder based simply upon either the fact of the execution of a given type of transaction or its value-destroying implications. ${ }^{145}$ As the fact that the transaction has taken place or the fact that value-destruction has ensued is enough to that end, no inquiry as to the drivers behind the transaction or the possibly ensuing value-destruction is required.

\section{Fair Value Protections and Unavoidable Value-destroying Trade Sales}

The safeguards and remedies seeking to protect fair value do fare well as long as ordinary firms are concerned. ${ }^{146}$ In fact, in this context, the firm value-maximization norm holds without exception, giving operational legitimacy to devices that have the potential to tackle a number of value-destroying transactions indiscriminately, such as fair value protections.

\footnotetext{
${ }^{144}$ Each of these options is the function of a policy approach that exhibits different levels of sensitivity to two important variables. One is the findings of corporate finance (as to the multitude of methodologies to be deployed to appraise a firm). Another is the need for contracting parties to avoid selecting a methodology a priori, making this selection rather the function of a choice that may factor in a variety of contingencies that are unknown ex ante (in a nutshell, to private ordering-based solutions in this area of the corporate contract). From this perspective, the first option appears manifestly superior. Its additional value lies in the fact that it acknowledges the variety of firm typologies and the complexity of the valuation process and the difficulty of determining the best methodology for a reliable figure a priori. It accordingly leaves the door open for contracting parties and possibly adjudicators to select one of the available valuation methodologies so as to adapt the valuation process to the firm's features and come up with as accurate a measure of firm value as possible, getting closer to fair value. The other two options stand, instead, in stark contrast. The second brings in a one-size-fits-all solution that, being informed by the ambition to deliver a unitary approach to firm valuation, may generate significant distortions due to its inflexibility. The third approach, in its attempt to allow for flexibility but without relinquishing the ambition to define the lowest end of the values lying on the fair value spectrum, seems to strike a compromise between the other two, but, at a closer look, denotes some regulatory paternalism that in practice may create non-negligible problems. To some extent, however, variations in the design of fair value protections also reflect the impact of 'forces' that do not play a formal role in policy-making. For an example and a brief discussion, see Giudici et al. (2020), pp 30-32.

145 This depends on the design of each fair value protection. For instance, fair value protections designed as a put-option work vis-à-vis a given list of transactions, regardless of their value-destroying potential, even though, intuitively, no shareholder will have incentives to activate such protection unless it is actually value-destroying. Again for instance, fair value protections that grant the shareholder external to decision-making a right of action against the company or the decision-maker for obtaining relief as to the resulting damages of a given transaction postulate, instead, that the transaction has actually resulted in value-destruction and that this outcome has affected the suing shareholder.

146 Despite some imperfections (e.g., they have the potential to generate hold-up dynamics), fair value protections (or, to be sure, 'some' fair value protections) have, in fact, the potential, in general, to filter out efficient and inefficient transactions and, thus, shield shareholders external to decision-making from the risk that they may be stripped of the fair value of their shareholdings. See Fischel (1983) discussing the fair value protection par excellence, i.e., US appraisal rights.
} 
The fair value protections that the standard corporate contract contemplates do apply to the trade sales of venture capital-backed firms in their various transactional forms ${ }^{147}$ : To the extent that this is the case, an entrepreneur faced with a valuedestroying trade sale can claim the pre-transaction value of his shareholding.

In the context of venture capital-backed firms, however, the quest for total shareholder value-maximization suffers from the limitations originating from the timeconstraints affecting the unfolding of the entrepreneur-venture capitalist business relationship. ${ }^{148}$ The arrangements that govern the entrepreneur-venture capitalist relationship imply that value-destruction is not inherently 'bad': unavoidable valuedestroying trade sales show that value-destruction can be the function of contractually-compliant instances of decision-making. ${ }^{149}$

Being the function of bright-line rules that imprint into them their simple mechanics, ${ }^{150}$ fair value protections are generally unable to appreciate the ultimate driver behind unavoidable value-destroying trade sales. As such, they tend to fail at recognizing the contractually compliant nature of unavoidable value-destroying trade sales, eventually proving irreconcilable with the logic of the contractual architecture that the entrepreneur and the venture capitalist typically conceive in order to adjust their relationship to the time-sensitive liquidity needs of the venture capitalist. ${ }^{151}$

The general availability of fair value protections does in fact enable the entrepreneur faced with an unavoidable value-destroying trade sale to claim the fair value of his shareholding, leading to an allocation of the value generated through this transaction that would then diverge from the allocation for which the entrepreneur and the venture capitalist typically bargain. That is, with fair value protections in place, the venture capitalist willing to carry out an unavoidable value-destroying trade sale would be able to do so only under the threat of an 'exit penalty'. Such exit penalty would obviously take away from the venture capitalist a given fraction of the value

$\overline{147}$ I.e., asset sales, asset combinations, or compelled share co-transfers: see above, n. 81 and corresponding text.

148 See above, Sect. 2.2.3.

149 See above, Sects. 3.2-3.3.

150 Such safeguards and remedies generally have their trigger event in a given list of transactions or in the fact of value-destruction per se without requiring any sort of enquiry into the driver behind the transaction or the ensuing value-destruction. See above, n. 145 and corresponding text.

151 To be sure, given that both premature value-destroying trade sales, which denote an opportunistic logic (see above, nn. 9-11 and corresponding text), and unavoidable value-destroying trade sales, which are contractually-compliant in nature, are possible moments of the life of venture capital-backed firms, fair value protections could fare well in this context too. Yet, they would fare well only if they could perform their protective function selectively-i.e., by tackling premature value-destroying trade sales, while simultaneously 'ignoring' unavoidable value-destroying trade sales. Fair value-protections, however, feature mechanics that are, by design, unapt to discern between the two. They work vis-à-vis a given list of transactions or value-destruction as such and thus are of potential use vis-à-vis any value-destroying trade sale. Such an approach would intuitively be at odds with the heterogeneous reality of value-destroying trade sales, leading to a contractual short circuit. In fact, these safeguards and remedies would practically shield entrepreneurs from both the value-destroying trade sales that opportunistically mark a departure from the bargain struck between entrepreneurs and the venture capitalist and value-destroying trade sales that are, to the contrary, just the function of bargained-for contractual arrangements. For details on the divide existing within the apparently homogenous category of value-destroying trade sales, see Nigro (2020), pp 1-8. 
Table 1 Exit penalty with non-participating liquidation preference

\begin{tabular}{llllll}
\hline & Value & Probability & TSV & EN's payoff & VC's payoff \\
\hline Acquisition offer & 61 & $100 \%$ & 61 & 1 & 60 \\
Scenario 1 & 160 & $50 \%$ & 80 & 64 & 96 \\
Scenario 2 & 10 & $50 \%$ & 5 & 0 & 10 \\
Average expected value & - & - & 85 & $64 * 0.5+0 * 0.5=32$ & $96 * 0.5+10 * 0.5=53$ \\
\hline
\end{tabular}

generated through these transactions: a fraction of value that the terms of the typical entrepreneur-venture capitalist contract would enable him to capture, instead.

To appreciate the side effects that the fair value protections available under the standard corporate contract could have in the context of an unavoidable valuedestroying trade sale as well as their practical implications, consider the two hypotheticals below, which build upon a set of assumptions ${ }^{152}$ and differ based on the design of the venture capitalist's liquidation preferences. ${ }^{153}$

Hypothetical 1-Alfa is a venture capital-backed firm in which the entrepreneur 'EN' holds a $40 \%$ plain-vanilla shareholding; and the venture capitalist 'VC' holds a $60 \%$ shareholding combined with a non-participating liquidation preference amounting to 60 million. $\mathrm{VC}$ has held a shareholding in Alfa for some 8 years. As the time to divest approaches, Alfa's expected value stands at some 85 million. After extending his support by 1 year, VC's fund has only a year left. ${ }^{154} \mathrm{VC}$ therefore goes shopping the firm in an adverse M\&A market. Only one potential acquirer appears, delivering Alfa a 61 million acquisition offer. 61 million is, therefore, the best value realizable on the M\&A market at the moment. The time constraints on the entrepreneur-venture capitalist relationship leave $\mathrm{VC}$ with no choice other than to opt for an immediate trade sale, with $\mathrm{VC}$ and EN accordingly receiving 60 and 1 million,

\footnotetext{
${ }_{152}$ Much in line with previous literature (see chiefly Fried and Ganor (2006), p 995, fn. 84), the discussion - and in particular the examples that will soon follow—build on the following assumptions. In addition to the assumptions made earlier (see above nn. 10 and 81), the entrepreneur and the venture capitalist are two risk-neutral agents without any time preference. Thus, cash flows are discounted at rate 1 . The expected firm value referred to in the discussion is therefore equivalent to net present value. Besides, the contract in this case provides for liquidation preferences that, whether participating or non-participating, feature neither cumulative dividends, nor compounding (on which, see above, n. 51). On a different note, as regards the scope of the discussion, value-destroying trade sales are here analysed for their impact on total shareholder value, particularly with a view to showing how fair value protections can reallocate value among entrepreneurs and venture capitalists. The discussion deliberately ignores, instead, the distributional effects between sellers and buyers and the ensuing implications.

153 On the varying design of liquidation preferences, see above, n. 53 and corresponding text.

${ }^{154}$ As per industry general trends, venture capital funds end after 8 years, but an extension is occasionally possible: see above, n. 36 .
} 
Table 2 Exit penalty with participating liquidation preference

\begin{tabular}{llllll}
\hline & Value & Probability & TSV & EN's payoff & VC's payoff \\
\hline Acquisition offer & 61 & $100 \%$ & 61 & 0.4 & 60.6 \\
Scenario 1 & 160 & $50 \%$ & 80 & 40 & 120 \\
Scenario 2 & 10 & $50 \%$ & 5 & 0 & 10 \\
Average expected value & - & - & 85 & $40 * 0.5+0 * 0.5=20$ & $120 * 0.5+10 * 0.5=65$ \\
\hline
\end{tabular}

respectively. ${ }^{155}$ Based on the valuation of Alfa at 85 million as well as the fact that fair value protections are available, EN would refuse to accept 1 million and demand a much more substantial cheque reflecting the pre-transaction value of his shareholding amounting to 32 million. Because of the disbursement resulting from this claim, VC would receive 29 million instead of 60 (Table 1). ${ }^{156}$

The pattern is similar and the outcome is identical in situations in which VC holds participating liquidation preferences—as shown below.

Hypothetical 2-Alfa has two shareholders EN and VC here too: EN holds a $40 \%$ plain-vanilla shareholding in Alfa, and VC holds $60 \%$ shareholding combined with a participating liquidation preference amounting to 60 million. Alfa's value stands, again, at some 85 million. VC invested 9 years ago and cannot postpone divestment any further. Such circumstances make the case for an immediate trade sale more and more compelling. Yet, due to temporarily depressed competition in the industry, the best acquisition offer from the few prospective buyers is in the form of a 61 million immediate cash-payment. Due to time-constraints VC cannot help but sell. VC and EN accordingly receive 60.6 and 0.4 million, respectively. As fair value protections are available, EN could reject the 0.4 million cheque and claim 20 million from VC, instead. By funnelling value towards EN, fair value protections lead to a situation in which VC's net payoff is just 41 million-i.e., almost 20 million down from the much higher figure of 60.6 million (Table 2). ${ }^{157}$

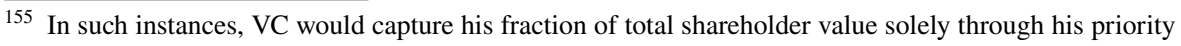
rights (on which see above, n. 53).

156 The same would apply, mutatis mutandis, if the financial burden were to fall on the acquirer (see above, n. 138), who would then factor in the penalty and reduce the acquisition offer accordingly.

${ }^{157}$ Here again, nothing would change if the financial burden were to fall on the acquirer: see above, $\mathrm{n}$. 138.
} 
As these examples show, the exit penalties in unavoidable value-destroying trade sales can be substantial, altering significantly the allocation of the value generated through unavoidable trade sales. ${ }^{158}$

\subsection{The Implications of Fair Value Protections' Design}

The potentially problematic nature of fair value protections in the context of venture capital-backed firms stems chiefly from the fact that they are simple functions of bright-line rules that do not require for an enquiry into the driver of the transaction. ${ }^{159}$ However, their varying design also plays an important role: responsible for the exit penalty and the ensuing distributive consequences ultimately are, in fact, the criteria for the determination of fair value.

Depending on their prescriptive contents, these criteria can both narrow or widen the discrepancy between the fair value of the entrepreneur's shareholding and the fraction of value generated by unavoidable trade sales that he would receive according to the entrepreneur-venture capitalist contract. By closing this discrepancy, these criteria can neutralize the threat stemming from fair value protections. Yet, by widening this discrepancy, they can render fair value protections more problematic.

\footnotetext{
${ }^{158}$ For instance, in the hypotheticals articulated in the text, the venture capitalist would have to pay to the entrepreneur between one third and a half of the value that he would be entitled to receive under the typical entrepreneur-venture capitalist contract. One additional notation is useful here. The venture capitalist may be exposed to the risk of an exit penalty regardless of whether he holds non-participating or participating liquidation preferences. The non-participating or participating nature of the liquidation preferences that the venture capitalist typically receive is nonetheless important. Recall that non-participating liquidation preferences require the venture capitalist to choose whether they want to capture his own fraction of total shareholder value through their priority rights or their participation rights. Participating liquidation preferences, instead, do not call for such a binary choice and the venture capitalist appropriates his own fraction of total shareholder value through both his priority and participating rights. See above, n. 53. Accordingly, a venture capitalist holding participating liquidation preferences would share in expected increases in total shareholder value, whichever their significance; and thereby correspondingly constrain the entrepreneur's participation in any expected increase in total shareholder value. By contrast, a venture capitalist holding non-participating liquidation preferences and capturing total shareholder value solely through his priority rights would allow the entrepreneur to capture any expected increase in total shareholder value in its entirety. The fair value that the entrepreneur would be able to claim in the second scenario would then be, all things being equal, comparatively greater. Consider the two following hypotheticals. In both hypotheticals, Alfa, within which the entrepreneur-venture capitalist relationship has since some time reached its terminal stage, receives a 61 million acquisition offer. Alfa's fundamental value is 65 million: there are, in fact, equally chances that the firm will be worth 90 or 40 . In the event of an immediate trade sale, VC would receive 60 or 60,6 million, depending on whether he holds non-participating or participating liquidation preferences. EN would correspondingly pocket, depending on the same variable, 1 or 0,4 million. If the firm were to stay independent for longer, VC would receive 50 or 59 , depending on whether the deal contemplated non-participating or participating liquidation preferences. EN's shareholding, instead, would be worth 15 or 6, depending, again, on the same variable. EN would therefore be able to claim, depending on contracting parties' choices as to the design of liquidation preferences, just 6 or 15 . All this suggests that, because of their different mechanics, non-participating liquidation preferences can, all things being equal, prove more problematic than participating liquidation preferences. Clearly, these conclusions hold only from an ex post perspective. They deliberately disregard the fact that, ex ante, the prospects of a greater exit penalty would lead contracting parties to redefine other the terms of their contract so to make up for any prospective increase in the entity of the potential exit penalty.

159 See above, n. 145 and above all 150-151 and corresponding text.
} 
Obviously, the larger this discrepancy, the more worrisome the prospects of the exit penalty, and ultimately the potentially more problematic fair value protections. ${ }^{160}$

The approach of the corporate contract to shaping this aspect of fair value protections may therefore have important consequences for the existence as well as the severity of the problem that they cause vis-à-vis unavoidable value-destroying trade sales. Recall that, when it comes to the criteria for the determination of fair value, the standard corporate contract can (i) leave the choice of these criteria open for ex post specification, (ii) delegate contracting parties to choose them ex ante, (ii) set them itself, or (iv) simply define a floor. ${ }^{161}$

All four approaches to fair value protections mentioned above can lead to situations in which the venture capitalist may have to compensate the entrepreneur for unavoidable value-destroying trade sales. Yet, a standard corporate contract that sets out its own criteria for the determination of fair value can make fair value protections more problematic. In fact, to the extent that these pre-set criteria can lead to firm valuations exceeding the value of the same venture capital-backed firm on the M\&A market, the standard corporate contract sets itself the stage for an exit penalty for the venture capitalist. A standard corporate contract that omits these criteria does not lead per se to the same consequences, instead.

\section{The Adaptation Process}

The availability of fair value protections has the potential to prevent contracting parties from allocating the value generated through unavoidable trade sales in a manner that is consistent with the contents of the typical entrepreneur-venture capitalist contract, which-as discussed-contemplates some instances of decision-making that leads to value-destruction. ${ }^{162}$

\footnotetext{
$\overline{160}$ Assume, for instance, that there are two identical venture capital-backed firms Alfa and Beta and that they are both involved in unavoidable value-destroying trade sales. The sole difference between the two scenarios is that, under the corporate contracts governing these two venture capital-backed firms, fair value is to be determined according to different criteria and, thus, valuation methodologies. The value of Alfa is to be determined by reference to all its future cash flows discounted to present value, whilst the value of Beta is to be determined by reference to the market value of its assets. Being largely insensitive to the conditions in the M\&A market, the value of Alfa would likely prove greater than the value that can be realized in the adverse M\&A market existing during the time-window available to carry out the transaction. Conversely, the value of Beta would likely to approximate the value that can be realized in the M\&A market within the time-window available to carry out the transaction. The fraction of the value generated by the unavoidable value-destroying trade sale that the entrepreneur would possibly claim vary correspondingly, and, with it, the exit penalty that the venture capitalist would accordingly have to bear.

${ }^{161}$ See above, nn. 139-143 and corresponding text.

162 See above, Sects. 2.2.3, 3.2 and 3.3.
} 
The entrepreneur and the venture capitalist may then want to adapt the contents of the standard corporate contract to the contents of the typical contractual framework governing venture capital-backed firms. The goal of the adaptation process would be to render the standard corporate contract 'tolerant' towards unavoidable value-destroying trade sales-or, more specifically, to ensure that the entrepreneur cannot claim more than the post-transaction value of his shareholding.

Although a complex process is involved in achieving this goal, ${ }^{163}$ one major step would consist in designing the corporate contract so as to neutralize the impact of fair value protections. To this end, any solution that practically enables the venture capitalist to liquidate his investments without paying any exit penalty is in principle fit for the purpose.

To begin with, some expedients could prove useful. Granting the venture capitalist a call-option on the entrepreneur's shareholding exercisable in the run-up to trade sales at a strike price that reflects the acquirer's offer may be of aid. In fact, by enabling the venture capitalist to buy out the entrepreneur at a price below fair value, such a 'pre-transaction squeeze-out' may eradicate the preconditions for the entrepreneur to claim fair value in the aftermath of the trade sale. ${ }^{164}$ The effectiveness of these arrangements is contingent upon two conditions: the arrangement must be enforceable and there cannot be a floor. Neither condition should be taken for granted. ${ }^{165}$ Yet, if these two conditions coexist, this expedient may help circumvent the problem.

Rather than playing around the issue, more effective solutions would seek to address it by overcoming the risk that the entrepreneur claim more than the posttransaction value of his shareholding.

One solution would consist in defining ex ante a point in time when protections are no longer available so as to deprive fair value protections of their bite once the venture capital-backed firm enters its divestment mode, above all as the venture capital fund's ends nears.

Another solution available to the entrepreneur and the venture capitalist would consist in relinquishing fair value protections altogether from the very beginning of their business relationship. Value-destruction through trade sales would then no longer be a concern. To this end, any private ordering-based solution with the effect of preventing the entrepreneur from availing himself of fair value protection would work. In particular, the contract can stipulate that the shareholder cannot avail

\footnotetext{
163 To this end, the adaptation process would concern at least two other institutions of the standard corporate contract: the rule governing the implementation of the corporate contract and, accordingly, the fiduciary standards that seek to guarantee that decision-making is loyally instrumental to implement the corporate contract according with that rule. For a discussion, see Nigro (2020).

164 Squeeze-outs are, in essence, transactions whereby the controlling shareholder buys out the non-controlling shareholder(s). Not by chance, in illustrating the mechanics of drag along provisions (on which see above, n. 67), the literature has explained that they incorporate a call-option on the entrepreneur's shareholding-which functionally corresponds to the pre-transaction squeeze-out mentioned in the text. For input in this respect, see Saez Lacave and Gutierrez (2010), pp 451-452; as well as Chemla et al. (2007), pp 116-117. On the usefulness of the technique mentioned in the text to circumvent fair value protections, see Coates (1999), p 1256; and, more recently, Fisch (2020), p 29.

165 In Italy, for instance, these arrangements may prove problematic in both respects. For details, see Nigro and Maltese (2020), pp 13-17.
} 
himself of fair value protections - that is, he is banned from doing so. Alternatively but practically equivalently, the contract can determine that the entrepreneur must vote (if, depending on the trade sale's form, he is required to do so) in favour of the transactions. In this case, the entrepreneur would no longer be eligible for availing himself of (at least some) fair value protections (namely, those that postulate that he has 'dissented' from the transaction the consequences of which he is now trying to escape). ${ }^{166}$

Another solution would consist in leaving fair value protections in place but simultaneously 'minimizing' their impact. For this purpose, it would be sufficient to stipulate ex ante that the fair value is to be determined in reference to the value that the venture capital-backed firm has on the M\&A market at the time of the unavoidable value-destroying trade sale. Under such arrangements, fair value protections would be available in theory, but would be bound to prove innocuous in practice. The implementation of this solution would partly vary depending on the design of fair value protections, particularly as concerns the way in which the standard corporate contract shapes the criteria for the determination of fair value. ${ }^{167}$ If the standard corporate contract leaves the choice of these criteria open for ex post specification or requires contracting parties to choose them ex ante, they can simply define fair value in reference to the value that the firm will have on the M\&A market. If, instead, standard corporate contract sets these criteria itself or defines a floor, contracting parties can 're-write' its contents in parte qua.

Roughly speaking, these three different techniques do not lead to different results. The first seems the easiest to implement; the second appears more linear; the third looks instead like an inadequate cousin.

These possible solutions, however, all imply to some degree an intrusion in the standard corporate contract. Their feasibility accordingly depends, then, on the fact the entrepreneur and the venture capitalist can adopt those private ordering-based solutions that may alter the availability of fair value protections or at least the way in which they operate: that is, their feasibility depends on the flexibility of fair value protections as regards their an or at least their quomodo.

\section{Implications}

For the entrepreneur and the venture capitalist to design an efficient contract, flexible fair value protections are-as just discussed-required.

The quest for flexible fair value protections should, however, consider that these safeguards and remedies generally perform a crucial positive function in shielding shareholders external to decision-making from decision-makers' opportunism. They are accordingly considered an essential — and thus, at least to some extent, ineliminable-component of the standard corporate contract. ${ }^{168}$ And this may suggest to

\footnotetext{
166 See again Fisch (2020), p 29, fn. 143 and corresponding text.

167 See above, nn. 139-143 and corresponding text, as well as Sect. 4.3.

168 See above, n. 129. For details, see Giudici et al. (2020), pp 19-25.
} 
take an a priori adverse stance towards the possibility of making fair value protections flexible.

There may be good reasons to consider whether it is appropriate to overcome this sort of conviction, though. The choice between injecting into fair value protections a more or less significant dose of flexibility may have, in fact, different consequences on contract formation and, accordingly and above all, on social welfare.

\subsection{Fair Value Protections, Contract Formation, and Social Welfare}

Economic theory portrays contracts as the function of contracting parties' ability to reach a given equilibrium. ${ }^{169}$ Corporate contracts are no exception. ${ }^{170}$ Their existence rests upon the successful outcome of a delicate bargaining process that seeks to reflect the unique nature of each business relationship. ${ }^{171}$

Insofar as the entrepreneur-venture capitalist relationship is concerned, bargaining is instrumental to endowing the venture capital-backed firm with their unique 'behavioural temperament', ${ }^{172}$ which needs to be such that the venture capitalist may be able to pursue, at a given point in time, his partisan interest to generate the timely liquidity that motivated investments in the first place.

A key to this outcome is the possibility to adapt the standard corporate contract to firm-specific realities. ${ }^{173}$ Within some limits, contracting parties can sidestep the obstacles created by overly rigid isolated contractual terms of the corporate contract-leading to variations in deal structures, but leaving unprejudiced the formation of the business relationship and thus overall levels of general welfare. ${ }^{174}$ Contracting parties' ability to modify the contract is nonetheless finite: at some point, value redistribution through other contractual terms is simply undoable. ${ }^{175}$

These general and essential notations as to how regulatory rigidities may affect contract formation help understanding the potential impact of fair value protection on the formation of the entrepreneur-venture capitalist contract. The premise is that fair value protections are poised to play a major role in the overall economy of entrepreneur-venture capitalist business relationships: as the grounds for a potentially

\footnotetext{
169 See, in general and for merely introductory purposes, Cooter and Ulen (2012), pp 277-287.

170 See, again, Easterbrook and Fischel (1989), pp 1420-1422; and Macey (1991), pp 1269-1273.

171 In fact, 'different firms have different needs, and different firms conduct their businesses in a very wide variety of contexts', implying that 'the various claimants to the cash flows could not customize the standard-form rules to meet their particular needs': see again Macey (1991), p 1270.

172 Indeed, "the "behaviour" of the firm is like the "behaviour" of a market; i.e., the outcome of a complex equilibrium process' (see, famously, Jensen and Meckling (1976), p 311) and, '[...] from a nexusof-contracts perspective, because firms consist of a complex web of contractual relationships, firm behaviour depends critically on what those contracts provide' (see Macey (1991), p 1272).

173 Macey (1991), pp 1272-1273. See also Hart (1989).

174 That is, contracting parties would simply redistribute value through other terms of the standard corporate contract, but would not give up to the prospect of engaging in value-creating cooperation. For references (concerning the venture capital context), see Armour and Cumming (2006), p 600, fn. 1.

175 See, in general and for merely introductory purposes, Cooter and Ulen (2012), pp 277-287.
} 
substantial exit penalty, these safeguards and remedies have the potential to significantly affect firm value allocation ex post. ${ }^{176}$

They therefore certainly have also the potential to affect investment decisions ex ante. And in fact, indications from transactional practice suggest that venture capitalists have a tangible interest in negotiating private ordering-based solutions with entrepreneurs that adapt this term of the corporate contract to the peculiar structure of venture capital-backed firms. ${ }^{177}$ Moreover, anecdotal evidence relating to the litigation concerning private ordering-based solutions used to solve the problem at the contractual stage serves as corroboration. ${ }^{178}$

Such indications from transactional practice do not warrant, however, the claim that fair value protections are necessarily deal-breakers, though. In some instances, the entrepreneur and venture capitalist may simply make up for the strictures stemming from the rigidities featuring such safeguards and remedies by redistributing value through other provisions of the standard corporate contract. In others, this option may simply be off. ${ }^{179}$

To the extent that this is the case, the non-negotiability of fair value protections stands in the way of the formation of the entrepreneur-venture capitalist contract, ${ }^{180}$ and, along with it, the creation of value, to the ultimate detriment of societal well-being. ${ }^{181}$

The potential adverse effect of fair value protections on contract formation recommends either making them just another default term of the standard corporate contract or at least allowing the re-shaping of the criteria used to determine fair value. Both solutions, as discussed earlier, ${ }^{182}$ would more or less linearly allow parties to

\footnotetext{
$\overline{176}$ See the simple examples articulated above, Sects. 4.2 and 4.3 .

177 One of these indications is the emphasis put on the matter in the context of the briefing by US law firms: see, for instance, Becker and Ahmadi (2019), as well as Dienstag et al. (2020). Another indication comes from extensive discussions with lawyers practising in both the US and Europe (particularly, but not exclusively, in Italy), who have confirmed that bargaining over fair value protection is a key moment of the negotiation process. Informal colloquia with some high-profile academics have in turn confirmed that they have been required of providing advice on the matter.

${ }^{178}$ For more details, see Manti Holdings LLC v. Authentix Acquisition Co., C.A. No. 2017-0887-SG, 2018 WL 4,698,255 (Del. Ch. October 1, 2018); and, above all, Manti Holdings, LLC et al. v. Authentix Acquisition Co., Civil Action No. 2017-0887-SG (Del. Ch, August 14, 2019). For a short account of the litigated facts and the court ruling, see, Becker and Ahmadi (2019), as well as Dienstag et al. (2020). See, above all, Fisch (2020). As to Europe (particularly Italy), see Nigro and Maltese (2020), pp 10-11, as well as Giudici et al. (2020), pp 13-15.

179 This follows from the general observation articulated earlier: see above, nn. 173-175 and corresponding text.

${ }^{180}$ See Bratton and Wachter (2013), p 1904 (presenting the same argument with regard to the disruptive effects that, because of its untailored nature to the reality of venture capital-backed firms, another key term of the standard corporate contract-namely, fiduciary standards-can have on the bargaining process and, accordingly, on the capital raising process). See also, more recently, Pollman (2019), p 218, fn. 331 and corresponding text.

${ }^{181}$ The point is intuitive: As long as a deal falters due to the impossibility to opt out of fair value protections, less value is produced.

182 See above, Sect. 5.
} 
neutralize the risk of a more or less substantial exit penalty that would clash with the logic of the typical entrepreneur-venture capitalist contract.

The additional value of increased flexibility in this area of the standard corporate contract is relatively straightforward. It would leave unimpaired the existing business relationships as well as the formation of those relationships that would be entered into in adherence under the corporate contract that makes fair value protections mandatory. However, it would also allow increased flexibility for those contracting parties that require it, and thus support the formation of those additional relationships that would be entered into only if fair value protection can be deactivated or at least reshaped. And even if only one additional value-creating deal were to fall under this umbrella, the resulting value-creation would be preferable to the status quo. It would in fact emerge as a superior option from a social welfare perspective. $^{183}$

\subsection{A Novel Policy Recommendation (with a Warning)}

The notations above support a novel, simple and clear-cut recommendation for policy-makers interested in drafting standard corporate contracts so as to better promote social welfare through venture capital ${ }^{184}$ : Making fair value protections just another default term of the standard corporate contract or at least injecting into their design a large dose of flexibility can help foster new business relationships.

It may come as a surprise that this policy recommendation is an entirely new one. Although policy-makers have started paying increasing attention to the problems that the strictures of the standard corporate contract can generate for prospective entrepreneurs and venture capitalists, they have thus far completely ignored the problem stemming out of fair value protections. ${ }^{185}$

There may be a reason for this 'indifference'. In their attempts to modernize the standard corporate contract, policy-makers have sought to remove those obstacles that were manifestly incompatible with the arrangements of the entrepreneur-venture capitalist contract responsible for defining the static structure of the venture capital-backed firm, with particular attention having been paid to the arrangements concerning the financing of the venture capital-backed firm. ${ }^{186}$ Perhaps due also

\footnotetext{
183 In the text, the suggestion is advanced that increased flexibility of fair value protections would result in the adoption of merely default rules. Yet, practically speaking, similar results could also be achieved if fair value protections were to be made the function of 'avoidable rules' of the corporate contract. On the concept of default and avoidable rules see above, n. 6. However practical equivalent, this solution seems overall slightly more convolute. Therefore, reference throughout this article is made only to the more linear solution consisting in resorting to default rules.

184 Which not only is the goal of an ideal social planner, but also the objective at the core of the various initiatives undertaken in various jurisdictions. See, for references, above, n. 14.

185 In Italy, for instance, fair value protections have been completely ignored throughout the policy-making process that eventually led to the adoption of a number of measures aimed at making the standard corporate contract more flexible, particularly with a view to easing the formation of new high-tech firms. Even commentators seem unconcerned: notable exceptions are Galletti (2000), pp 244-245; and, more recently and at length, both Nigro and Maltese (2020) and Giudici et al. (2020).

186 For references, see above, n. 16.
} 
to the lack of any pertinent theorization, policy-makers have not focused on the explicit and implicit arrangements that shape the evolutionary trajectory of the venture capital firm, instead. They have paid even less attention to the implications that the changing structure of these firms may have on the dynamics underlying specific transactions, such as trade sales. They have not considered, in particular, whether, due to implicit contractual contents, instances of contractually-compliant valuedestruction may exist.

Understanding these arrangements is nonetheless crucial for an appreciation of the problems that fair value protections may cause as the venture capitalist's liquidity needs become increasingly compelling - and, more broadly speaking, as venture capital-backed firms enters into divestment mode.

Yet, policy-makers interested in modernizing the standard corporate contract to make it more amenable to prospective entrepreneurs and venture capitalists should not confine their attention to fair value protections. They should, instead, heed the following warning: The evolving structure of venture capital-backed firms requires a complex, multi-step adaptation of the standard corporate contract that also implies the re-moulding of fair value protections. However, other institutions of the standard corporate contract can also stand in the way of unavoidable value-destroying trade sales, neutralizing the advantage of increased flexibility in the design of fair value protections. ${ }^{187}$

Unavoidable value-destroying trade sales therefore call for an injection of flexibility into various traditional institution of the the standard corporate contract. And more broadly speaking, conceiving a venture capital-friendly standard corporate contract should therefore be seen as an endeavour that can succeed only if, giving due consideration to the firm-specific reality of venture capital-backed firms from both a static and dynamic perspective, it does holistically aim at featuring appropriate levels of flexibility along all those dimensions that are generally affected by the pervasive adaptation process that the entrepreneur and the venture capitalist typically undertake. ${ }^{188}$

\section{Conclusions}

This paper has analysed fair value protections in unavoidable value-destroying trade sales. The starting point of the discussion is the acknowledgment that the epicentre of the venture capital industry consists of venture capital funds with a fixed-term that serves an efficiency function. To support the efficient implementation of the contract governing the venture capital fund, the venture capitalist negotiates terms with the entrepreneur that may result in the braiding of their contract with that governing the venture capital fund.

\footnotetext{
187 Reference in the text is made, intuitively, to fiduciary standards. See above, nn. 18 and 180.

188 A notable example is, in the varying shapes in which it appears across jurisdictions, the so-called 'corporate opportunities doctrine'. For a discussion that helps appreciating the potentially problematic nature of this term of the standard corporate contract, see, e.g., Hellgardt (2010), p 766.
} 
Braiding informs contract ambitions, affects contract formal design, and defines the logic of contract implementation. As a result, venture capital-backed firms typically exhibit a biphasic structure with a time to invest preceding a time to divest, reflected in formal contract structures that vest the venture capitalist with a number of explicit prerogatives instrumental to divestment. More importantly, the venture capitalist receives also an implicit 'termination option' that, at a given point, enables him to divest irrespective of any contingency.

The core of the entrepreneur-venture capitalist contract is a straightforward agreement to pursue value creation but within a given timespan. Accordingly, the contractual framework contemplates instances that prioritize timely liquidity over value maximization, potentially resulting in value destruction.

Unavoidable value-destroying trade sales are perhaps the most apparent manifestation of the venture capitalist's decision to exercise his termination option. The fair value protections that the standard corporate contract contemplates may expose the venture capitalist to the risk of an exit penalty that may alter the allocation of the value generated through these transactions that the typical entrepreneur-venture capitalist contract stipulates.

To avoid this outcome and pave the way for value allocation in line with the contents of the typical entrepreneur-venture capitalist contract, contracting parties may want to adapt fair value protections to the specific reality of venture capital-backed firms by resorting to expedients or a variety of more or less linear techniques. All these solutions do postulate, however, flexible fair value protections. They should be just another default term of the standard corporate contract or at least be largely malleable as regards the criteria according to which fair value is to be determined.

To the extent that the negotiability of fair value protections is a precondition for the formation of a given number of additional business relationships, a standard corporate contract contemplating flexible fair value protections does emerge, from a social welfare perspective, as a superior option.

The reasoning articulated herein adds a piece to both the scholarly discussion and the policy debate. On the one hand, it sheds light into our understanding of the dynamics unfolding as the venture capital-backed firm matures, particularly as regards the drivers behind the decision-making process observable in the runup to the divestment, particularly through trade sales. On the other hand, it makes a recommendation to policy-makers interested in modernizing the standard corporate contract so as to support venture capital investments and, hence, promote social welfare.

This research is, however, just a first step taken on an unexplored path. Future complementary research-both theoretical and empirical-is required. To begin with, research should clarify the scope of the termination option. Chances are that the venture capitalist has more discretion in pursuing his own partisan interests than either currently supposed or explicit contractual contents suggest. The 'expansion' of the scope of the termination option would make room for additional instances of contractually compliant instances of decision-making with potentially value-destroying implications. This, in turn, would widen the universe of situations where overly rigid fair value protections may prove problematic. 
Also, empirical research should aim to clarify the impact of non-negotiable fair value protections on venture capital investments so as to build a more solid basis for compelling normative conclusions. Research should also map the stance taken by existing corporate laws with regard to fair value protections and the ultimate dynamics underlying these differences and their implications with a view to understanding what may possibly stand in the way of their modernization. More broadly speaking, the peculiar structure of venture capital-backed firms calls for an increase in attention with regard to how the standard corporate contract interacts with the firm-specific exigencies that emerge in this context, particularly as venture capital-backed firms evolves.

Efforts made in this direction will prove more profitable if placed in the context of broader research that seeks to make up for the under-investigated nexus between the standard corporate contract and venture capital investments, with a view to gaining a better understanding of how the former can support the latter-to the ultimate benefit of social welfare.

Acknowledgements Professor Brigitte Haar was a great scholar, wonderful person, and generous spirit, with whom Casimiro A. Nigro had the honour of working closely, and whose absence is deeply felt. Haar's brilliant scholarly career was marked, inter alia, with a fascination for the interaction between corporate and contract law, and in particular by the complexities of the contractual arrangements that are typical of venture capital financing (see, above all, Haar (2001), Haar (2004), Haar (2006), Haar (2008a) and Haar (2008b)). Her encouragement and generosity, which persisted despite her limited time and through to their very last meeting, was indispensable in fostering the development of the idea explored in this paper, as well as its eventual submission to this journal. It is altogether fortunate, therefore, that this piece, first presented during the Symposium held at the Goethe University on 25 September 2019 to commemorate her, is now poised to be included in the resulting special issue, contributing to her legacy in a more permanent form. For useful discussions and/or comments on a previous draft, the authors thank above all, Luca Enriques, Tobias Tröger, Curtis Milhaupt, Jahred Ellias, and Vincenzo Pezone, as well as Peter Agstner, Danny Blaustein, Sergio Gilotta, Paolo Giudici, Pedro Magalhães Batista, Chiara Lacava, Demetrio Maltese, Alessandro Romano, Andrea Sacco Ginevri, Mathias Siems, Matthias Thiemann, Holger Spamann, and Cornelia Woll. Ian Leo Polakiewicz has provided outstanding linguistic assistance. The usual disclaimers apply. This research benefitted from the funding by the Deutsche Forschungsgemeinschaft-DFG (Project 'FOR 2774'). Jörg R. Stahl acknowledges also funding through grants UID/ GES/00407/2013 and PTDC/EGE-OGE/30314/2017 of the Portuguese Foundation for Science and Technology-FCT.

Funding Open Access funding enabled and organized by Projekt DEAL.

Open Access This article is licensed under a Creative Commons Attribution 4.0 International License, which permits use, sharing, adaptation, distribution and reproduction in any medium or format, as long as you give appropriate credit to the original author(s) and the source, provide a link to the Creative Commons licence, and indicate if changes were made. The images or other third party material in this article are included in the article's Creative Commons licence, unless indicated otherwise in a credit line to the material. If material is not included in the article's Creative Commons licence and your intended use is not permitted by statutory regulation or exceeds the permitted use, you will need to obtain permission directly from the copyright holder. To view a copy of this licence, visit http://creativecommons.org/licen ses/by/4.0/. 


\section{References}

Aghion P, Bolton P, Tirole J (2004) Exit options in corporate finance: liquidity versus incentives. Rev Financ 8:327-353

Amit R, Brander J, Zott C (1998) Why do venture capital firms exist? Theory and Canadian evidence. J Bus Ventur 13:441-466

Armour J (2003) Law, innovation, and finance. In: McCahery JA, Renneboog L (eds) Venture capital contracting and the valuation of high-technology firms. Oxford University Press, Oxford, pp 133-161

Armour J, Cumming DJ (2006) The legislative road to Silicon Valley. Oxford Economic Papers 58:596-635

Armour J, Hansmann H, Kraakman R, Parglender M (2017a) What is corporate law. In: Armour J, Enriques L, Kraakman R, Davies P, Hansmann H, Hertig G, Hopt KJ, Kanda H, Parglender M, Ringe W-G, Rock E (eds) The anatomy of corporate law: a comparative and functional approach, 3rd edn. Oxford University Press, Oxford, pp 1-28

Armour J, Hansmann H, Kraakman R (2017b) Agency problems and legal strategies. In: Armour J, Enriques L, Kraakman R, Davies P, Hansmann H, Hertig G, Hopt KJ, Kanda H, Parglender M, Ringe W-G, Rock E (eds) The anatomy of corporate law: a comparative and functional approach, 3rd edn. Oxford University Press, Oxford, pp 29-48

Bainbridge SM (2012) Mergers and acquisitions, 3rd edn. Foundation Press, New York

Baird DG, Henderson MT (2008) Other people's money. Stanford Law Rev 60:1309-1343

Bartlett RP III (2006) Venture capital, agency costs, and the false dichotomy of the corporation. UCLA Law Rev 54:37-117

Basha A, Walz U (2002) Financing practices in the German venture capital industry: an empirical assessment. Center for Financial Studies Working Paper No 08. https://www.ifk-cfs.de/fileadmin/downl oads/publications/wp/02_08.pdf. Accessed 27 July 2020

Baums T, Möller M (1999) Venture capital: U.S.-amerikanisches Modell und deutsches Aktienrecht. ILF-Institute for Law and Finance Working Paper No 83/1999. https://www.jura.uni-frankfurt. de/43031695/paper83.pdf. Accessed 27 July 2020

Becker A, Ahmadi P (2019) Waiver of appraisal right in a stockholder agreement is enforceable under Delaware law. K\&L Gates Briefing report of 18 October 2019. https://www.klgatesdelawaredocke t.com/2019/10/waiver-of-appraisal-rights-in-a-stockholder-agreement-is-enforceable-under-delaw are-law/. Accessed 27 July 2020

Bengtsson O (2012) Financial contracting in US venture capital financing. In: Cumming DJ (ed) The Oxford handbook of venture capital. Oxford University Press, Oxford, pp 478-508

Berger AN, Udel GF (1998) The economics of small business finance: the roles of private equity and debt markets in the financial growth cycle. J Bank Financ 22:613-673

Bienz C, Walz U (2010) Venture capital exit rights. J Econ Manag Strategy 19:1071-1116

Birdthistle WA, Henderson MT (2009) One hat too many? Investment desegregation in private equity. Univ Chicago Law Rev 76:45-82

Black BS, Gilson RJ (1995) The law and finance of corporate acquisitions, 2nd edn. Foundation Press, Westbury

Black BS, Gilson RJ (1998) Venture capital and the structure of capital markets: banks versus stock markets. J Financ Econ 47:243-277

Black BS, Gilson RJ (1999) Does venture capital require an active stock market? J Appl Corp Financ $11: 36-48$

Bratton WW (2002) Venture capital on the downside: preferred stock and corporate control. Mich Law Rev 100:891-945

Bratton WW, Wachter ML (2013) A theory of preferred stock. Univ Pa Law Rev 161:1815-1906

Braun R, Weik S, Achleitner A-K (2020) Follow the money: how venture capital facilitates emigration of firms and entrepreneurs in Europe. https://papers.ssrn.com/sol3/papers.cfm?abstract_id=3415370. Accessed 27 July 2020

Broughman BJ, Fried JM (2010) Renegotiation of cash flow rights in the sale of VC-backed firms. J Financ Econ 95:384-399

Broughman BJ, Fried JM (2013) Carrots and sticks: how VCs induce entrepreneurial teams to sell startups. Cornell Law Rev 98:1321-1357

Broughman BJ, Fried JM (2020) Do founders control start-up firms that go public? Harvard Bus Law Rev 10:49-86 
Chatterji A, Patro A (2014) Dynamic capabilities and managing human capital. Acad Manag Perspect 28:395-408

Chemla G, Habib MA, Ljungqvist A (2007) An analysis of shareholder agreements. J Eur Econ Assoc 5:93-121

Cheng C, Sun Y, Su Y, Yang S (2019) Venture capital, innovation, and growth: evidence from Chinese metropolitan data. Appl Econ Lett 26:549-553

Clark RC (1986) Corporate law. Little Brown, Boston

Coase RH (1937) The nature of the firm. Econometrica 4:386-405

Coates JC IV (1999) Fair value as an avoidable rule of corporate law: minority discounts in conflict transactions. Univ Pa Law Rev 147:1251-1359

Coates JC IV (2018) Mergers, acquisitions and restructuring: types, regulation, and patterns of practice. In: Gordon JN, Ringe WG (eds) The Oxford handbook of corporate law and governance. Oxford University Press, Oxford, pp 570-601

Cohen WM, Levinthal DA (1990) Absorptive capacity: a new perspective on learning and innovation. Adm Sci Q 35:128-152

Cooter R, Freedman BJ (1991) The fiduciary relationship: its economic character and legal consequences. N Y Univ Law Rev 66:1045-1076

Cooter R, Ulen T (2012) Law and economics, 6th edn. Pearson, Boston

Coyle JF, Polsky GD (2013) Acqui-hiring. Duke Law Journal 63:281-346

Cumming DJ, Johan SA (2009) Venture capital and private equity contracting, 1st edn. Elsevier, Oxford

Damodaran A (2010) Applied corporate finance, 3rd edn. Wiley, Hoboken

Davies P (2016) The transactional scope of takeover law in comparative perspective. European Corporate Governance Institute (ECGI)_Law Working Paper No 313/2016. https://papers.ssrn.com/sol3/ papers.cfm?abstract_id=2749266. Accessed 27 July 2020

DePamphilis D (2014) Mergers, acquisitions, and other restructuring activities, 7th edn. Elsevier, Oxford

DeTienne DR (2010) Entrepreneurial exit as a critical component of the entrepreneurial process: theoretical development. J Bus Ventur 25:203-215

Dienstag AL, Moriarty JJ, Wechsler EL (2020) Protecting drag-along rights in private equity deals. Kramer Levin M\&A Monitor, 22 January 2020. https://www.kramerlevin.com/en/perspectivessearch/protecting-drag-along-rights-in-private-equity-deals.html. Accessed 27 July 2020

Duchin R, Schmidt B (2013) Riding the merger wave: uncertainty, reduced monitoring, and bad acquisitions. J Financ Econ 107:69-88

Easterbrook FH, Fischel DR (1989) The corporate contract. Columbia Law Rev 89:1416-1448

Enriques L, Macey JR (2001) Creditors versus capital formation: the case against the European legal capital rules. Cornell Law Rev 86:1165-1204

Enriques L, Hansmann H, Kraakman R, Parglender M (2017) The basic governance structure: minority shareholders and non-shareholder constituencies. In: Armour J, Enriques L, Kraakman R, Davies P, Hansmann H, Hertig G, Hopt KJ, Kanda H, Parglender M, Ringe W-G, Rock E (eds) The anatomy of corporate law: a comparative and functional approach, 3rd edn. Oxford University Press, Oxford, pp 79-108

Faria AP, Barbosa N (2014) Does venture capital really foster innovation? Econ Lett 122:129-131

Fisch JE (2020) Appraisal waivers. European Corporate Governance Institute (ECGI)—Law Working Paper No 537/2020. https://ecgi.global/sites/default/files/working_papers/documents/fischfinal _0.pdf. Accessed 30 November 2020

Fischel DR (1983) The appraisal right remedy in corporate law. Am Bar Found Res J 8:875-902

Fried JM, Ganor M (2006) Agency costs of venture capitalist control in startups. N Y Univ Law Rev $81: 967-1025$

Galletti D (2000) Il recesso nelle società di capitali. Giuffrè, Milan

Gao X, Ritter JR, Zhongyan Z (2013) Where have all the IPOs gone? J Financ Quant Anal 48:1663-1692

Gilson RJ (2003) Engineering a venture capital market: lessons from the American experience. Stanford Law Rev 55:1067-1103

Gilson RJ (2010) Locating innovation: the endogeneity of technology, organizational structure, and financial contracting. Columbia Law Rev 110:885-917

Gilson RJ, Sabel CF, Scott RE (2010) Braiding: the interaction of formal and informal contracting in theory, practice, and doctrine. Columbia Law Rev 110:1377-1447

Giudici P, Agstner P (2019) Startups and company law: the competitive pressure of Delaware on Italy (and Europe?). Eur Bus Org Law Rev 20:597-632 
Giudici P, Agstner P, Nigro CA (2020) Venture capital-backed firms and trade sales: do US and EU corporate laws get them right? A comparative exercise (on file with the authors)

Gompers PA (1995) Optimal investment, monitoring, and the staging of venture capital. J Financ 50:1461-1489

Gompers PA (1996) Grandstanding in the venture capital industry. J Financ Econ 42:133-156

Gompers PA, Lerner J (2001) The venture capital revolution. J Econ Perspect 15:145-168

Gompers PA, Ivashina V, Ruback RS (2019) Private equity. A casebook. Anthem Press, London-New York

Gorbenko AS, Malenko A (2018) The timing and method of payment in mergers when acquirers are financially constrained. Rev Financ Stud 31:3937-3978

Gordon Smith D (2005) The exit structure of venture capital. UCLA Law Rev 53:315-356

Goshen Z, Hamdani A (2015) Corporate control and idiosyncratic vision. Yale Law J 125:560-795

Graham JR, Smart SB, Adam A, Gunasingham B (2016) Introduction to corporate finance. Gengage AU, Sydney

Haar B (2001) Venture capital funding for biotech pharmaceutical companies in an integrated financial services market: regulatory diversity within the EC. Eur Bus Org Law Rev 2:585-602

Haar B (2004) Impressions of the first RICAFE conference: risk capital and the financing of European innovative firms. Eur Bus Org Law Rev 5:201-205

Haar B (2006) Die Personengesellschaft im Konzern. Privatautonomie zwischen Vertrag und Organisation, Mohr Siebeck, Tübingen

Haar B (2008a) Gesellschaftsrechtsformen der Innovationsfinanzierung. Governance-Strukturen im Recht der Limited Partnership. In: Baum H, Hellgardt A, Fleckner AM, Roth M (eds) Perspektiven des Wirtschaftsrechts. Deutsches, europäisches und internationales Handels-, Gesellschafts- und Kapitalmarktrecht. Beiträge für Klaus J. Hopt aus Anlass seiner Emeritierung. De Gruyter Recht, Berlin, pp 141-166

Haar B (2008) Law and finance-Kapitalmarktentwicklung in interdisziplinärer Perspektive. Juristen Zeitung 63:964-974

Hall RE, Woodward SE (2010) The burden of the non-diversifiable risk of entrepreneurship. Am Econ Rev 100:1163-1194

Hart O (1989) An economist's perspective on the theory of the firm. Columbia Law Rev 89:1757-1774

Hebert RF, Link AN (1988) The entrepreneur-mainstream views and radical critiques, 2nd edn. Praeger, New York

Hellgardt A (2010) Abdingbarkeit der gesellschaftsrechtlichen Treuepflicht. In: Baum H, Hellgardt A, Fleckner AM, Roth M (eds) Perspektiven des Wirtschaftsrechts. Deutsches, europäisches und internationales Handels-, Gesellschafts- und Kapitalmarktrecht. Beiträge für Klaus J. Hopt aus Anlass seiner Emeritierung. De Gruyter Recht, Berlin, pp 765-794

Hussinger K (2010) On the importance of technological relatedness: SMEs versus large acquisitions. Technovation 30:57-64

Jensen MC, Meckling WH (1976) Theory of the firm: managerial behavior, agency costs and ownership structure. J Financ Econ 3:305-360

Kanda H, Levmore S (1985) The appraisal remedy and the goals of corporate law. UCLA Law Rev 32:429-473

Kaplan SN, Strömberg P (2003) Financial contracting theory meets the real world: an empirical analysis of venture capital contracts. Rev Econ Stud 70:281-315

Kaplan SN, Strömberg P (2004) Characteristics, contracts, and actions: evidences from venture capitalist analyses. J Financ 59:2177-2210

Katz AM (2019) Addressing the harm to common stockholders in Trados and Nine Systems. Columbia Law Rev 118:234-264

Kershaw D (2016) Principles of takeover regulation. Oxford University Press, Oxford

Kim JO (2018) Asset specificity and firm value: evidence from mergers. J Corp Financ 48:375-412

Klausner M, Litvak K (2001) What economists have taught us about venture capital contracting. Stanford Law School John M. Olin Program in Law and Economics Working Paper 221/2001. https://www. ssrn.com/abstract $=280024$. Accessed 27 July 2020

Klausner M, Venuto S (2013) Liquidation rights and incentive misalignment in start-up financing. Cornell Law Rev 98:1399-1436

Korsmo CR (2013) Venture capital and preferred stock. Brooklyn Law Rev 78:1163-1230

Kortum S, Lerner J (2000) Assessing the contribution of venture capital to innovation. RAND J Econ 31:674-692 
Krumm BK (2017) Fostering innovation and entrepreneurship: shark tank shouldn't be the model. Arkansas Law Rev 70:553-608

Lemley MA, McCreary A (2020) Exit strategy. Stanford Law and Economics Olin Working Paper \#542. https://papers.ssrn.com/sol3/papers.cfm?abstract_id=3506919. Accessed 27 July 2020

Lerner J (1994) The syndication of venture capital investments. Financ Manag 23:16-27

Lerner J (2007) The governance of new firms: a functional perspective. In: Lamoreaux NR, Sokoloff KL (eds) Financing innovation in the United States-1870 to present. MIT, Cambridge, pp 405-432

Lerner J, Nanda R (2020) Venture capital's role in financing innovation: what we know and how much we still need to learn. National Bureau of Economics (NBER)—Working Paper No 27492

Litvak K (2009) Venture capital limited partnership agreements: understanding compensation arrangements. Univ Chicago Law Rev 76:161-218

Macey JR (1991) Fiduciary duties as residual claims: obligations to non-shareholder constituencies from a theory of the firm perspective. Cornell Law Rev 84:1266-1281

Margolin BA, Kursh S (2005) The economics of Delaware fair value. Delaware J Corp Law 30:413-436

Maynard TH, Warren DM (2014) Business planning: financing the start-up business and venture capital financing, 2nd edn. Wolters Kluwer, New York

McCahery JA, Vermeulen EM (2003) Business organization law and venture capital. In: McCahery JA, Renneboog L (eds) Venture capital contracting and the valuation of high-technology firms. Oxford University Press, Oxford, pp 162-187

Meier J-M, Servaes H (2019) The bright side of fire sales. Rev Financ Stud 32:4228-4270

Milgrom P, Roberts J (1992) Economics, organization, and management. Prentice Hall, Englewood Cliffs

Neville M, Sørensen KE (2014) Promoting entrepreneurship — the new company law agenda. Eur Bus Org Law Rev 15:545-584

Nigro CA (2019) Venture capital-backed firms, trade sales e tutela dell'imprenditore tra shareholder value maximization e equa valorizzazione (Tesi di dottorato). https://papers.ssrn.com/sol3/paper s.cfm?abstract_id=3669088. Accessed 27 July 2020

Nigro CA (2020) Venture capital, trade sales, and dynamic fiduciary duties (on file with the author)

Nigro CA, Maltese D (2020) Private equity, fusione e rinuncia preventiva all'appraisal right: brevi note su un caso statunitense (con ampia veduta sul diritto societario italiano) (on file with the author)

Pargendler M (2008) Modes of gap filling: good faith and fiduciary duties reconsidered. Tulane Law Rev 82:1315-1354

Pollman E (2019) Startup governance. Univ Pa Law Rev 168:155-221

Popov A, Roosenboom P (2013) Venture capital and new business creation. J Bank Financ 37:4695-4710

Pratt SP (1989) Defining standards of value. Valuation 34:1-12

Priester H-J (2010) Drag along- und Call Option Klauseln in der GmbH-Satzung. In: Grundmann S, Haar B, Merkt H, Mülbert PO, Wellenhofer, Baum HH, von Hein J, von Hippel T, Pistor K, Roth M, Schweitzer H (eds) Festschrift für Klaus J Hopt. Band I. Unternehmen, Market, und Verantwortung. De Gruyter, Berlin, pp 1139-1151

Robb AM, Robinson DT (2014) The capital structure decisions of new firms. Rev Financ Stud 27:153-179

Rock EB, Wachter ML (1999) Waiting for the omelet to set: match-specific assets and minority oppression in the close corporation. J Corp Law 1999:913-948

Rock EB, Davies P, Kanda H, Kraakman R, Ringe W-G (2017) Fundamental changes. In: Armour J, Enriques L, Kraakman R, Davies P, Hansmann H, Hertig G, Hopt KJ, Kanda H, Parglender M, Ringe W-G, Rock E (eds) The anatomy of corporate law: a comparative and functional approach, 3rd edn. Oxford University Press, Oxford, pp 172-204

Roth GH, Kindler P (2013) The spirit of corporate law. Core principles of corporate law in continental Europe. Beck-Hart-Nomos, Munich

Ruhnka JC, Young JE (1991) Some hypotheses about risk in venture capital investing. J Bus Ventur 6:115-133

Saez Lacave MS, Gutierrez NB (2010) Specific investments, opportunism and corporate contracts: a theory of tag-along and drag-along clauses. Eur Bus Org Law Rev 11:423-458

Sahlman WA (1990) The structure and governance of venture capital organizations. J Financ Econ 27:473-521

Samila S, Sorenson O (2011) Venture capital, entrepreneurship, and economic growth. Rev Econ Stat 93:338-349

Sawicki A (2015) Buying teams. Seattle Univ Law Rev 38:651-684

Schwartz A, Scott RE (2003) Contract theory and the limits of contract law. Yale Law J 113:541-619 
Shleifer A, Vishny RW (1992) Liquidation values and debt capacity: a market equilibrium approach. J Financ 47:1343-1366

Shleifer A, Vishny RW (2003) Stock market driven acquisitions. J Financ Econ 70:295-311

Shleifer A, Vishny RW (2011) Fire sales in finance and macroeconomics. J Econ Perspect 25:29-48

Smith R (2012) Required rate of return and financial contracting for entrepreneurial ventures. In: Cumming DJ (ed) The Oxford handbook of venture capital. Oxford University Press, Oxford, pp $448-477$

Strine LE Jr (2013) Poor pitiful or potently powerful preferred? Univ Pa Law Rev 161:2025-2040

Vermeulen EM (2003) The evolution of legal business forms in Europe and the United States. Venture capital, joint venture, and partnership structures. Kluwer Law International, The Hague

Vermeulen EM (2018) Capital markets union: why 'venture capital' is not the answer to Europe's innovation challenge. In: Busch D, Ferrarini G, Avgouleas E (eds) Capital markets union in Europe. Oxford University Press, Oxford, pp 193-207

Wansley M (2019) Beach money exits. J Corp Law 45:151-215

Williamson O (1975) Markets and hierarchies. Analysis and anti-trust implications. The Free Press, Chicago

Zider B (1998) How venture capital works. Harvard Bus Rev 76:131-139

Publisher's Note Springer Nature remains neutral with regard to jurisdictional claims in published maps and institutional affiliations.

\section{Authors and Affiliations}

\section{Casimiro A. Nigro ${ }^{1}$ Jörg R. Stahl ${ }^{2}$}

Jörg R. Stahl

jstahl@ucp.pt

1 Center for Advanced Studies On the Foundations of Law and Finance, Goethe Universität, Frankfurt am Main, Germany

2 Universidade Católica Portuguesa, Lisbon, Portugal 